INTER NATIONAL MONETARY FUND
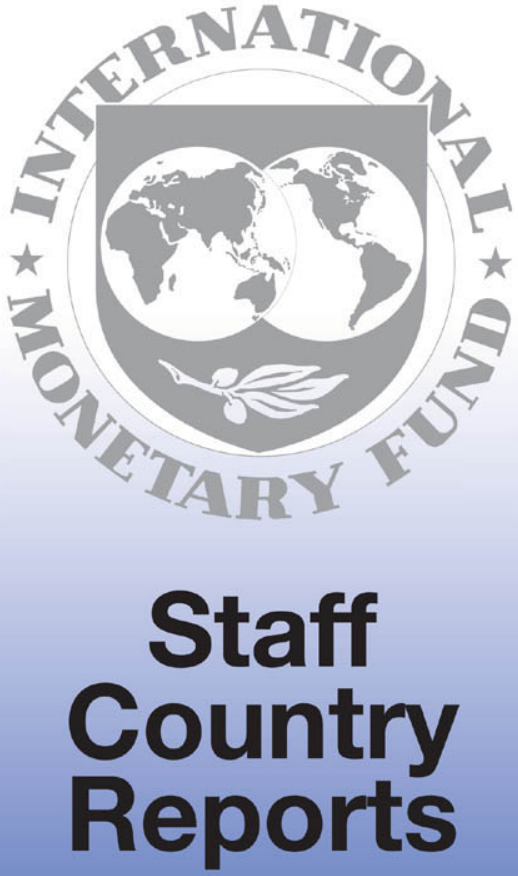


\section{Sweden: Staff Report for the 1999 Article IV Consultation}

This report was prepared by a staff team of the International Monetary Fund following discussions with the officials of Sweden on economic developments and policies. The report was then considered by the IMF's Executive Board in the context of the IMF's periodic consultation with Sweden, as required under Article IV of the IMF Articles of Agreement. The views expressed in the staff report itself are those of the staff team and do not necessarily reflect the views of the Executive Board of the IMF or of the authorities of Sweden; a supplementary statement by IMF staff may also be included. The views of the Executive Board as expressed in the discussion of the Article IV consultation report and as summarized in a Public Information Notice (PIN) are also included. In addition, a statement by the member country authorities may be appended. Further background documentation prepared by IMF staff for the consultation may be published separately at a later date. The policy of publication of Article IV staff reports allows for the deletion of market sensitive information.

This Article IV staff report is published-both in hard copy and on the IMF's website (http://www.imf.org) - as part of a pilot project. To assist the IMF in evaluating the pilot project for release of Article IV staff reports, reader comments on the staff report are invited prior to October 5, 2000, and may be sent by e-mail to Pilotproject@imf.org.

Copies of this report are available to the public from

International Monetary Fund $\bullet$ Publication Services 700 19th Street, N.W. • Washington, D.C. 20431

Telephone: (202) 623-7430 • Telefax: (202) 623-7201

Telex (RCA): 248331 IMF UR

E-mail: publications@imf.org

Internet: http://www.imf.org

Price: $\$ 15.00$ a copy

\section{International Monetary Fund \\ Washington, D.C.}




\section{INTERNATIONAL MONETARY FUND}

\section{SWEDEN}

\section{Staff Report for the 1999 Article IV Consultation}

Prepared by the Staff Representatives for the 1999 Consultation with Sweden

Approved by Jacques R. Artus and Carlos G. Muniz

August 4, 1999

- The consultation discussions were held in Stockholm during May 19-26, 1999.

- The staff team comprised Mr. Boughton (Head, SEC), Mr. Thomas (EU1), Mr. Swinburne (MAE), and Ms. Cerra (EU1). Mr. Hansen, Executive Director for Sweden, participated in some of the discussions.

- The staff representatives met with Minister of Finance Ringholm, Riksbank Governor Bäckström, officials of the Riksbank, the Ministry of Finance, the Ministry of Industry, Employment and Communications, the Financial Management Authority, the National Institute of Economic Research, the Financial Supervisory Authority, and the head of Statistics Sweden; as well as representatives of unions, employers, private financial institutions, and academics.

- The authorities released the staff team's concluding statement to the public and have agreed to participate in the pilot project for publication of Staff Reports.

- Sweden accepted the obligations of Article VIII, sections 2, 3 and 4, on March 15, 1961, and subscribes to the Special Data Dissemination Standard. The authorities have completed the questionnaire circulated in conjunction with the Code of Good Practices on Fiscal Transparency. 


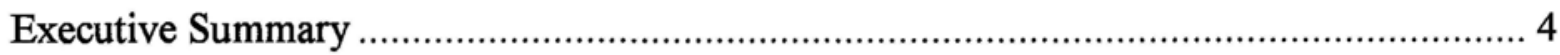

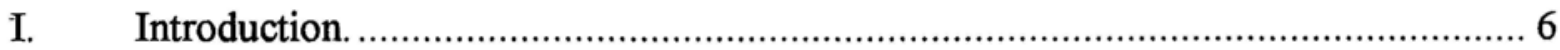

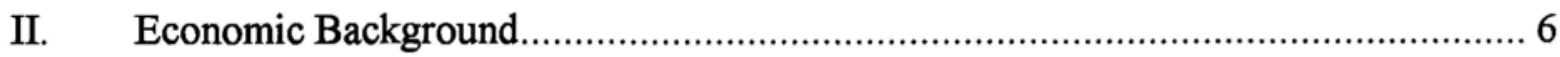

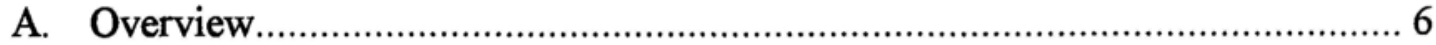

B. Recent Economic Developments ...................................................... 7

C. Policies....................................................................................21

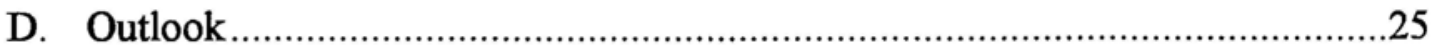

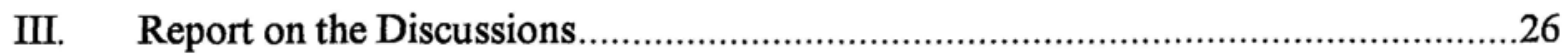

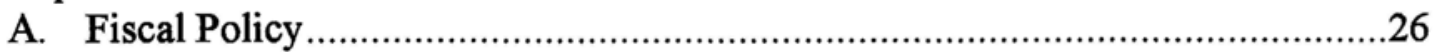

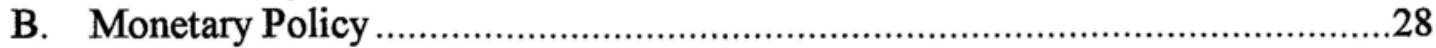

C. Structural Policies ...............................................................................

The labor market .............................................................................

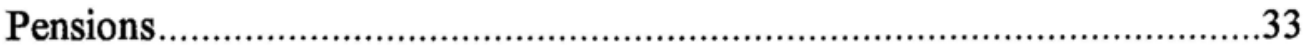

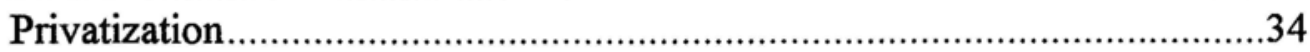

The financial sector ...........................................................................34

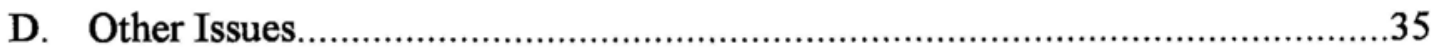

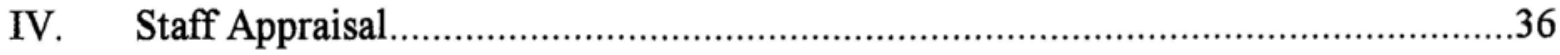

Text Boxes

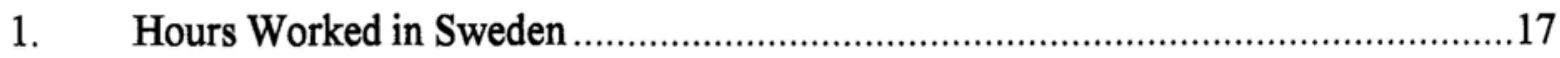

2. Pension Reform ..........................................................................................24

3. Labor and Capital Taxes in Selected Industrial Countries.......................................29

$\underline{\text { Tables }}$

1. Selected Economic and Financial Indicators .................................................... 8

2. Contributions to Changes in Household Real Disposable Income ...........................12

3. Balance of Payments.................................................................................

4. General Government Finances .................................................................22

Figures

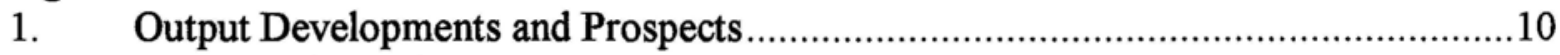

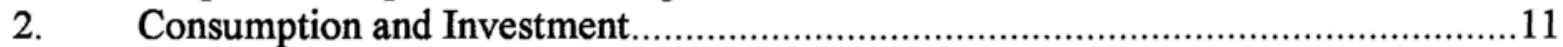

3. Labor Market Developments..........................................................................15

4. Inflation Developments..................................................................................16

5. Exchange Rate Developments...............................................................19

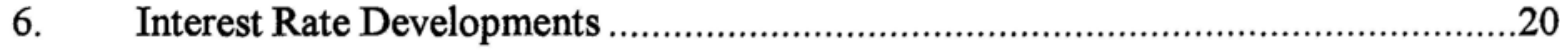

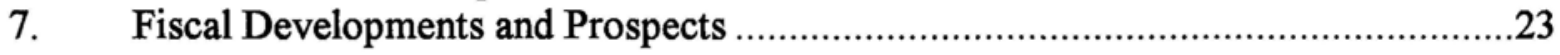




\section{Appendices}

1. Basic Data 39

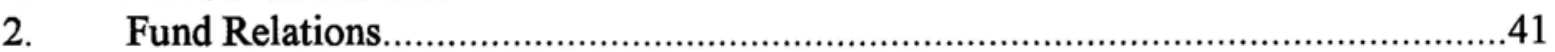

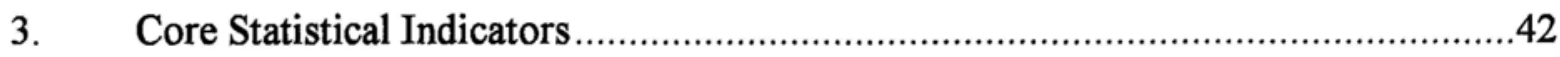




\section{EXECUTIVE SUMMARY}

Background: Sweden is benefiting from the macroeconomic reforms undertaken since 1993, including the adoption of an inflation target and a strong fiscal consolidation program. The success of these policies has been demonstrated by exceptionally low inflation, a competitive and generally stable floating exchange rate, a fiscal surplus, and moderate economic growth. The challenge for the authorities now is to build on this success through structural reform measures in taxation and wage formation.

Policy discussions: Given the success of macroeconomic policies in recent years, differences of view between the staff and the authorities centered on nuances and priorities rather than fundamentals. Contentions were most marked with regard to structural reforms.

- On fiscal policy, the central issue concerned the scope for tax cuts in the next few years. The staff supported the authorities' goal of averaging a 2 percent fiscal surplus over the business cycle and agreed that it was likely that revenues could be cut by up to 1 or 2 percent of GDP in 2001 and 2002 without threatening that objective. Moreover, Sweden's high taxation level made some reduction essential over the medium term. The difficulty was that output could be very close to potential in those years; additional stimulus could raise inflationary pressures. To help resolve that conflict, the staff recommended broadening the range of taxes to be reduced, designing the cuts so as to promote structural reform in the economy, and introducing further reductions in government spending.

- The staff and the authorities agreed that Sweden has a solid financial position and economic policies that in most respects are not out of line with the rest of Europe. The Government therefore has reason to feel confident as it approaches a decision on whether to join the European Monetary Union.

- On monetary policy, cuts in interest rates and indirect taxes have pushed CPI inflation well below the 1-3 percent target range for the past three years, while the underlying inflation rate is estimated to have stayed closer to the lower end of that range. That pattern has generated public criticism that interest rates should have been cut earlier and more aggressively, which the Riksbank has been at pains to counter. The staff agreed that the current policy stance was appropriate but urged the authorities to switch the inflation target explicitly to an index of underlying inflation.

- The staff pressed the authorities to implement deeper reforms in the labor market, including by lowering replacement rates and tightening eligibility requirements in assistance for the unemployed and by promoting greater and more rational differentiation of wages across skill levels. The authorities stressed the political difficulties of changing systems of social assistance and wage formation that were integral components of the Swedish approach to social welfare. 


\section{Key issues:}

- Would Sweden benefit from a tax reduction in the near future, or are tax cuts inherently problematic in an economy nearing full employment? Should spending be cut as well, to offset the stimulus from tax reduction? If taxes are to be cut, how should they be structured so as to provide the greatest benefit to the economy?

- In economic terms, would Sweden benefit from joining EMU? Is the current inflation targeting regime an appropriate strategy in preparation for a possible entry, or should more attention be paid to the exchange rate?

- If the wage formation process were reformed, from one based on industry-level bargaining to one that was less centralized and promoted greater wage dispersion, would this make a significant contribution to economic performance? If a decentralized system is not politically feasible, would it be better to shift to a more centralized system to limit wage drift or to leave the process alone?

- How can the social choice to provide a generous system of unemployment insurance and other public benefits best be reconciled with the need to reduce structural impediments to economic performance? 


\section{INTRODUCTION.}

1. At the conclusion of the last consultation on September 14, 1998 (EBM/98/85), Executive Directors noted that the implementation of monetary policy in an inflation targeting framework had effectively achieved price stability and that the fiscal consolidation program had eliminated the sizeable deficit that Sweden had experienced during the early 1990s. However, Directors voiced concerns about the slow pace of structural reform and warned that the proposed shift to fiscal stimulus at the turn of the century could rekindle inflation. Some Directors encouraged Sweden to keep EMU participation under active consideration.

\section{The Social Democratic Party remained in office following the elections in} September 1998, but a decline in support necessitated forming a coalition with the Left and Green parties to achieve a majority in parliament. In October, the Government announced that the unemployment target (reducing the open unemployment rate by half, to 4 percent by end-2000) would be supplemented by a longer-range and possibly more ambitious target for employment (raising a narrowly defined employment ratio from 75 to 80 percent). ${ }^{1}$ The Government has not yet made a commitment to enter the European Monetary Union (EMU). In January, the Prime Minister announced that the Social Democratic Party would indicate its position at a specially convened party congress in the spring of 2000 , with a possible referendum that autumn.

\section{ECONOMIC BACKGROUND}

\section{A. Overview}

3. The Swedish economy came under severe pressure in the early 1990s when a number of forces - high wage and price inflation, the bursting of a bubble in real estate prices and bank shares, a consequent banking crisis, and a forced exit from the currency peg against the Ecu-brought on the country's deepest recession since the 1930s. ${ }^{2}$ The damaging effects from the combination of high public sector employment, generous welfare benefits, high tax rates, and a high sensitivity of government finances to the business cycle were laid bare by the recession and led to a loss of confidence in the credibility of Sweden's financial policies. Since then the authorities have done much to restore stability and credibility, through a swift resolution of the banking crisis and the adoption of solid

\footnotetext{
${ }^{1}$ The objective is measured by the ratio of total employment to the working-age population aged between 20 and 64 . The staff estimates that an 80 percent ratio is likely to imply an unemployment rate below 4 percent, though the relationship depends on the success of ongoing programs (discussed below) to raise labor market participation.

${ }^{2}$ From 1991 to 1993 , real GDP declined by 5 percent, and by 1994 unemployment had risen by 8 percentage points to 13 percent.
} 
macroeconomic policies centered on inflation targeting and a strong fiscal consolidation program. The success of these policies has been evidenced since 1993 by exceptionally low inflation and a competitive and generally stable floating exchange rate; and more recently by a fiscal surplus and moderate economic growth. Progress on structural reform-especially on taxation and wage formation has been less pronounced.

\section{B. Recent Economic Developments}

\section{Real GDP growth picked up to slightly below 3 percent in 1998 , as a result of a} strengthening of domestic demand. Investment surged by $91 / 2$ percent after declining by $43 / 4$ percent the year before; private consumption rose by $2 \frac{1}{2}$ percent ( 2 percent in 1997); and public consumption rose by nearly 2 percent (minus $1 / 2$ percent in 1997). (See Table 1 and Figures 1 and 2 . $^{3}$ Investment was boosted by a combination of improved profit conditions, a healthy economic outlook, and lower interest rates. Private consumption was aided by sizeable real wage increases and increased government transfers to households (Table 2), as well as by declining unemployment and rising asset prices. Not all of these developments are sustainable, and domestic demand growth is tapering off this year. Inventories also are expected to decline, as business surveys indicate dissatisfaction with large stocks of both raw materials and finished goods. As a corollary, however, import growth is also slowing, so that net exports are contributing an expected $1 / 2$ percent (minus $1 / 2$ percent in 1998) to aggregate GDP growth. The output gap is estimated to have been slightly above 2 percent of GDP in $1998 .^{4}$

\section{The external current account has improved considerably since Sweden} abandoned its fixed exchange rate in 1992 and allowed the krona to depreciate. The surplus reached nearly 3 percent of GDP in 1997 before falling to 2 percent in 1998 on account of a weakening in both services and net merchandise exports. (See Table 3.) For the next few years, the current account is expected to remain in surplus provided that Sweden's competitiveness is maintained and the anticipated world economic upswing materializes.

\footnotetext{
${ }^{3}$ The data discussed here are based on the Swedish system of national accounts, which differs from the standardized European system (ENA95). In late May, Statistics Sweden published its first GDP data based on ENA95, which raised the reported level of nominal GDP by about 4 percent. Real GDP growth for 1998 was revised downward to 2.6 percent, while the average growth rate for 1994-98 was broadly similar to the previous estimate. These new data are still incomplete (current account estimates are preliminary, and no official forecasts have been made) and therefore are not discussed further in this report.

${ }^{4}$ It should be noted that the extent of excess capacity in any economy is difficult to estimate. The staff calculation of the output gap in Sweden is in line with official estimates, but these figures should be interpreted cautiously. For a detailed analysis, see Chapter I in "Sweden-Selected Issues" (August 1999).
} 
Table 1. Sweden: Selected Economic and Financial Indicators

(Percent change, unless otherwise noted)

\begin{tabular}{|c|c|c|c|c|c|c|c|}
\hline & \multirow[b]{2}{*}{1994} & \multirow[b]{2}{*}{1995} & \multirow[b]{2}{*}{1996} & \multirow[b]{2}{*}{1997} & \multirow[b]{2}{*}{1998} & \multicolumn{2}{|c|}{ Staff projections } \\
\hline & & & & & & 1999 & 2000 \\
\hline Real domestic demand & 2.6 & 2.5 & -0.3 & 0.9 & 3.9 & 2.5 & 2.7 \\
\hline Public consumption & -0.7 & -1.0 & -1.7 & -0.4 & 1.9 & 1.2 & 0.6 \\
\hline Private consumption & 1.8 & 0.8 & 1.3 & 2.0 & 2.6 & 3.0 & 2.5 \\
\hline Gross fixed investment & 2.0 & 12.4 & 3.7 & -4.8 & 9.6 & 6.3 & 6.0 \\
\hline Stocks $1 /$ & 1.4 & 0.5 & -1.1 & 0.7 & 0.3 & -0.5 & 0.1 \\
\hline External balance 1/ & 0.9 & 1.5 & 1.2 & 1.4 & -0.6 & 0.6 & 0.1 \\
\hline Exports of goods and services & 14.0 & 12.9 & 6.1 & 12.8 & 7.3 & 4.8 & 6.0 \\
\hline Imports of goods and services & 13.2 & 10.2 & 3.7 & 11.7 & 11.0 & 4.5 & 6.0 \\
\hline Real GDP & 3.3 & 3.9 & 0.9 & 2.2 & 2.9 & 2.8 & 3.0 \\
\hline \multicolumn{8}{|l|}{ Inflation } \\
\hline Consumer price index & 2.2 & 2.5 & .0 .5 & 0.5 & -0.1 & 0.2 & 1.0 \\
\hline \multicolumn{8}{|l|}{ Employment and unemployment } \\
\hline Employment & -0.9 & 1.6 & -0.6 & -1.1 & 1.5 & 1.5 & 1.2 \\
\hline $\begin{array}{l}\text { Open unemployment (as percent } \\
\text { of labor force) }\end{array}$ & 8.0 & 7.7 & 8.0 & 8.0 & 6.5 & 5.8 & 5.4 \\
\hline $\begin{array}{l}\text { Labor market programs } \\
\text { (as percent of labor force) }\end{array}$ & 5.3 & 4.4 & 4.5 & 4.3 & 3.9 & 3.6 & 3.6 \\
\hline \multicolumn{8}{|l|}{ Business excluding agriculture } \\
\hline Hourly wages & 2.4 & 3.3 & 6.0 & 4.5 & 3.8 & 3.0 & 3.8 \\
\hline Productivity & 3.0 & 2.9 & 1.8 & 3.2 & 1.7 & 1.2 & 2.7 \\
\hline Unit labor costs & -0.6 & 0.4 & 4.2 & 1.3 & 2.1 & 1.8 & 1.1 \\
\hline \multicolumn{8}{|l|}{ Manufacturing } \\
\hline Hourly wages & 3.1 & 5.4 & 6.6 & 4.5 & 3.5 & 2.5 & 3.7 \\
\hline Productivity & 9.2 & 5.8 & 2.5 & 6.5 & 2.2 & 2.2 & 3.5 \\
\hline Unit labor costs & -6.1 & -0.4 & 4.1 & -2.0 & 1.3 & 0.3 & 0.2 \\
\hline \multicolumn{8}{|l|}{ Household sector } \\
\hline Real disposable income & 1.4 & -1.0 & -0.6 & -1.4 & 2.6 & 3.4 & 1.9 \\
\hline Saving ratio $2 /$ & 8.0 & 6.3 & 4.4 & 1.1 & 1.2 & 2.1 & 1.6 \\
\hline $\begin{array}{l}\text { External current account balance } \\
\text { (as percent of GDP) }\end{array}$ & 0.4 & 2.4 & 2.6 & 2.9 & 2.1 & 1.7 & 1.7 \\
\hline
\end{tabular}

Sources: Ministry of Finance; Statistics Sweden; the Riksbank; and staff estimates.

1/ Contribution to GDP growth.

2/ Percent of GDP. 
Table 1. (Continued) Sweden: Selected Economic and Financial Indicators

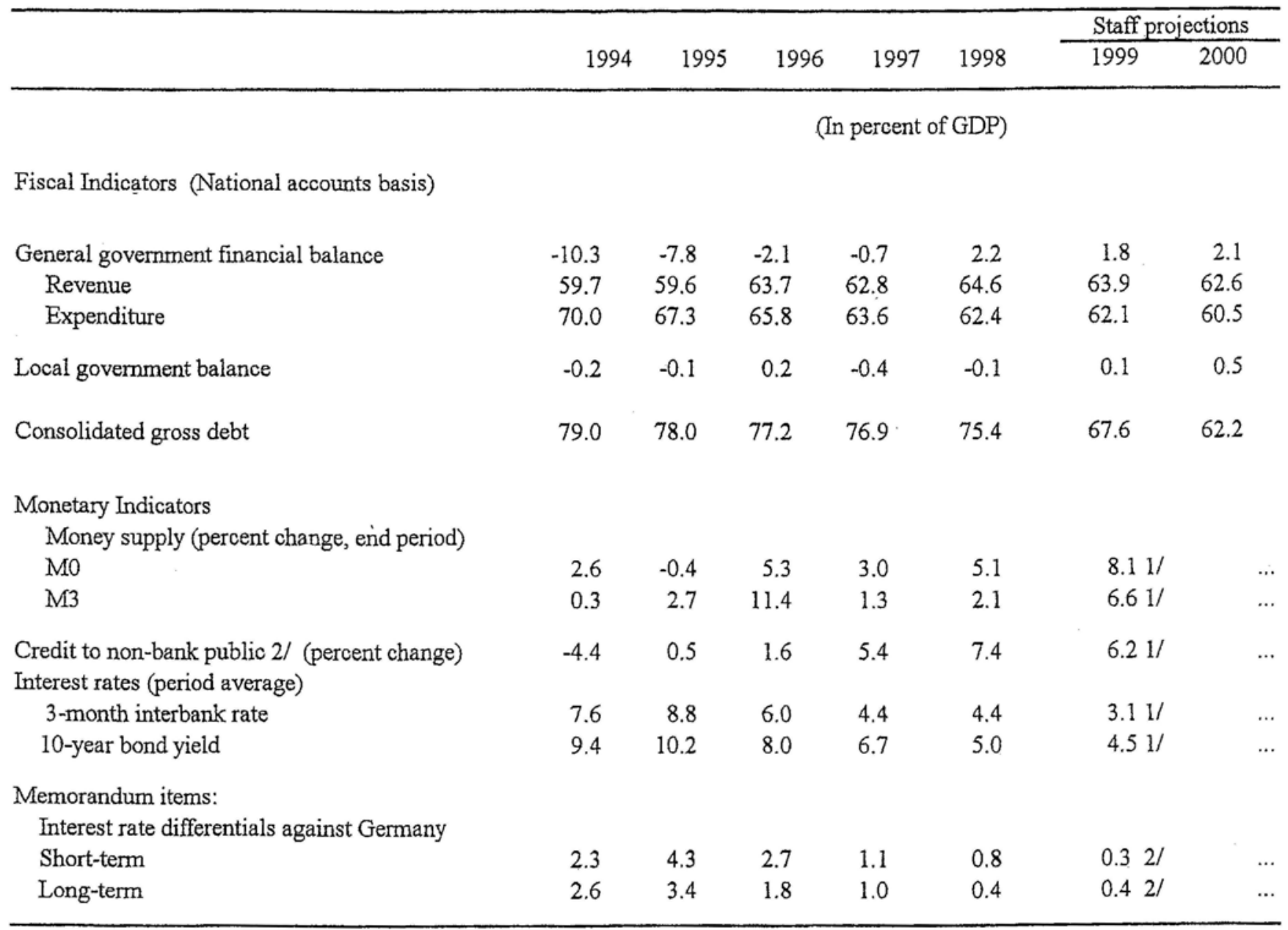

Sources: Ministry of Finance; the Riksbank; and IFS.

1/ May 1999.

2/ April 1999. 
OUTPUT DEVELOPMENTS AND PROSPECTS

(Annual percentage change)
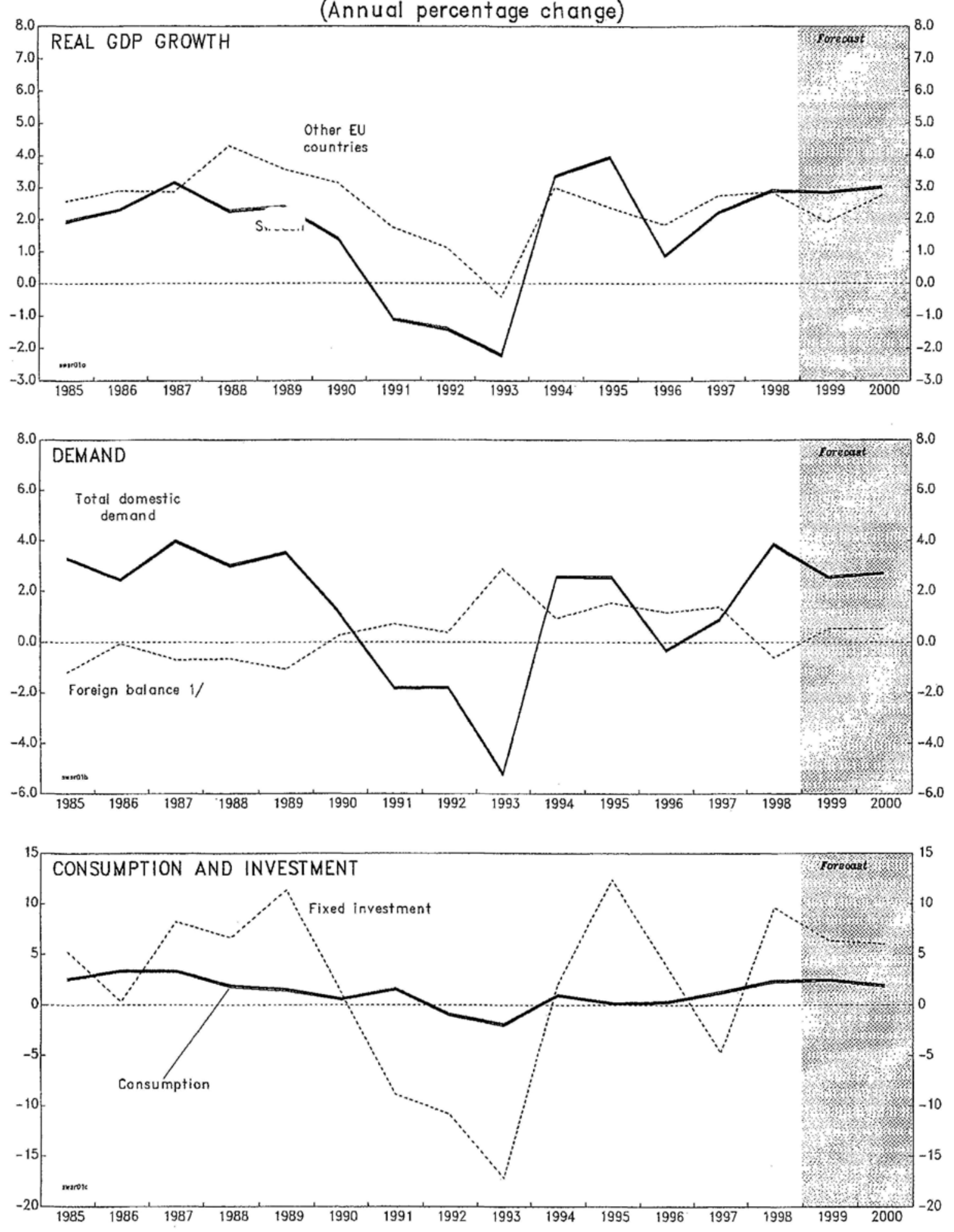

Sources: Statistics Sweden; and staff estimates.

1) Contribution to GDP growth. 
FIGURE 2

SWEDEN

CONSUMPTION AND INVESTMENT

(Annual percent change)
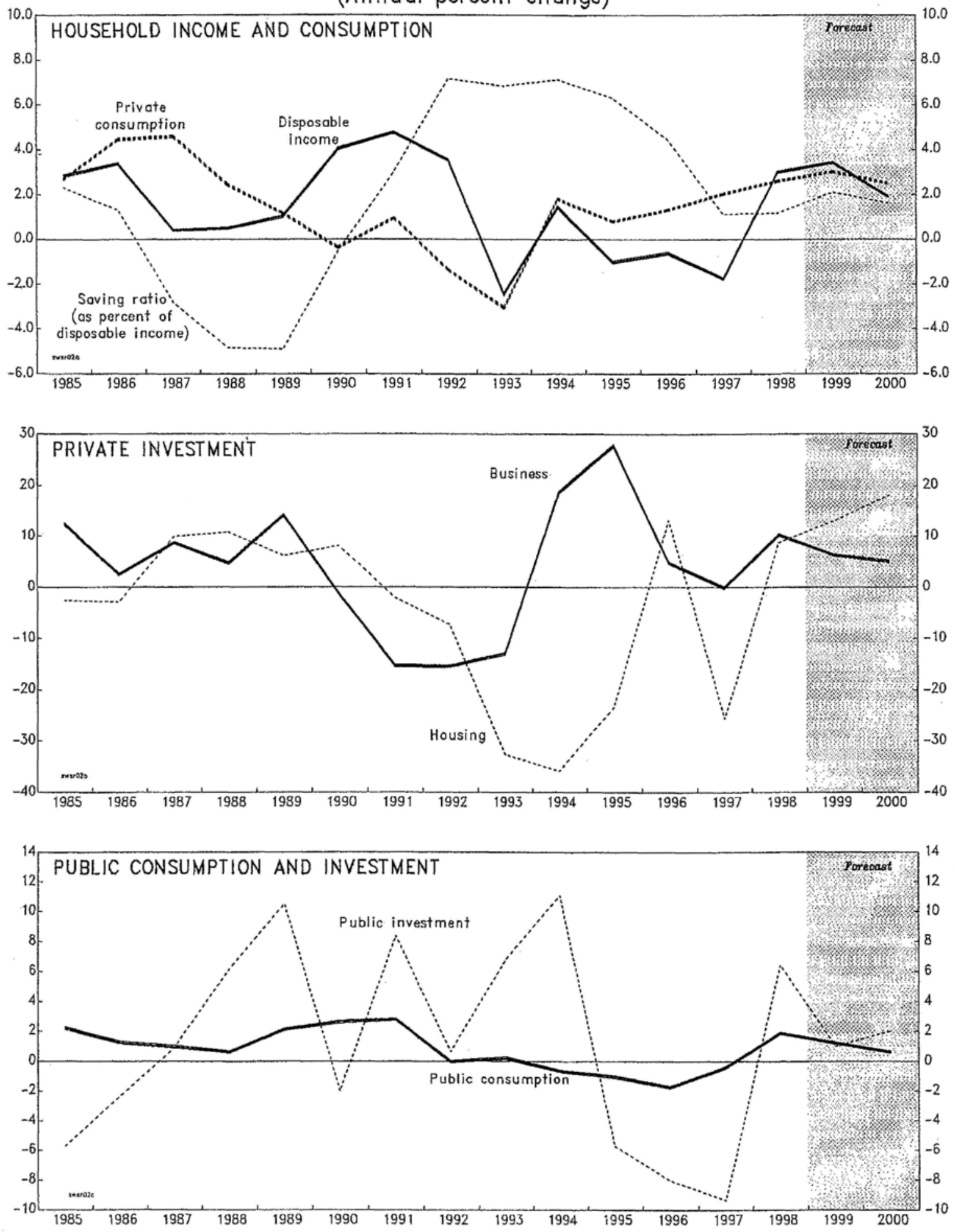

Sources: Statistics Sweden and staff estimates. 
Table 2. Sweden: Contributions to Changes in Household Real Disposable Income (Percentage points, unless otherwise noted)

\begin{tabular}{|c|c|c|c|c|c|}
\hline & 1994 & 1995 & 1996 & 1997 & 1998 \\
\hline Disposable income (percent change) & 1.4 & -1.0 & -0.7 & -1.4 & 2.6 \\
\hline \multicolumn{6}{|l|}{ Contributions from: } \\
\hline Wages & 0.9 & 1.6 & 3.4 & 1.4 & 4.9 \\
\hline Other factor income & 1.6 & 1.0 & -0.3 & 0.2 & 0.0 \\
\hline Taxes and transfers, net & -1.1 & -3.6 & -3.8 & -3.0 & -2.3 \\
\hline Taxes and contributions & -2.0 & -2.5 & -2.8 & -2.2 & -3.5 \\
\hline Transfers & 0.9 & -1.1 & -1.0 & -0.8 & 1.2 \\
\hline Private consumption (percent change) & 1.8 & 0.8 & 1.3 & 2.0 & 2.6 \\
\hline Saving rate (change) & & -1.7 & -1.9 & -3.3 & 0.1 \\
\hline Saving rate (percent of disposable income) & 8.0 & 6.3 & 4.4 & 1.1 & 1.2 \\
\hline
\end{tabular}

Sources: National Institute of Economic Research; Ministry of Finance, and staff calculations. 
6. Labor markets strengthened in 1998, but much room for improvement remains. Employment increased by nearly 3 percent year on year through the second quarter of 1999 and raised the broadly defined employment-population ratio slightly above 73 percent (Figure 3). ${ }^{5}$ The open unemployment rate fell by more than a percentage point during the past year to below $5 \frac{1}{2}$ percent in the second quarter, largely as a consequence of rising domestic demand. Government labor market programs, however, still employed around $3 \frac{1}{2}$ percent of the labor force. With wages highly compressed across age groups and education levels, unemployment has been especially high among younger and less educated workers. Moreover, weekly hours worked in industry (about 35) -although typical for Europe-remain well below the industrial-country average (40). ${ }^{6}$

7. Consumer price inflation has been exceptionally low in Sweden since early 1996, below the EU average and the Riksbank's 2 percent inflation target (Figure 4). In 1996 and 1997, the low CPI inflation rate was largely the effect of declining mortgage costs associated with the 5 percentage point fall in interest rates, reinforced by reductions in indirect taxes. Since then, declining import prices have also helped to stabilize the CPI. Excluding the effects of interest costs and indirect taxes, the twelve-month inflation rate has averaged about 1 percent since early 1997 but has risen in recent months to 1.5 percent in June. The "harmonized" (HICP) inflation rate is currently 0.4 percent.

8. The main risk to price stability is from wages. Although nominal wage increases have moderated, real wages are still growing faster than productivity. Wages rose by about 4 percent in 1998, compared with increases of about 5 percent in both 1996 and 1997, but that moderation primarily reflected lower inflation expectations rather than labor market slack. Deflated by expected inflation (as indicated in surveys), real wages are still growing around 3 percent per annum, compared with an estimated $1 \frac{1}{2}$ percent rate of increase in labor productivity. The latest wage projections from both employer and employee organizations suggest that this pattern is continuing in 1999.

\section{The Swedish krona came under selling pressure in the second half of $\mathbf{1 9 9 8}$ but} has since recovered. Last fall, when international turbulence in financial markets was at its peak, the krona fell to its lowest level in effective terms since early 1995 (Figure 5). That decline, which appears to have been precipitated mainly by expectations of further domestic interest rate cuts and to have been aggravated by regional contagion, prompted the Riksbank to respond through exchange market intervention. After the turn of the year, although the krona weakened against the U.S. dollar, it strengthened against the euro by about $73 / 4$ percent through June (with most of the rise coming in January). To some extent, that strengthening is

\footnotetext{
${ }^{5}$ This is the standard measure of the employment-population ratio, defined as the ratio of total employment to the population aged between 16 and 64 (cf. Footnote 1).

${ }^{6}$ The other industrial countries included in this comparison are the United States, Canada, Japan, Belgium, Denmark, France, Germany, Italy, the Netherlands, Norway, and the United Kingdom. Source: U.S. Dept. of Labor, Bureau of Labor Statistics. For a perspective on hours worked, see Box 1.
} 
Table 3. Sweden: Balance of Payments (In billions of US Dollars)

\begin{tabular}{|c|c|c|c|c|c|}
\hline & 1994 & 1995 & 1996 & 1997 & 1998 \\
\hline Current account surplus & 1.6 & 5.5 & 6.5 & 6.6 & 4.6 \\
\hline (in percent of GDP) & 0.8 & 2.4 & 2.6 & 2.9 & 2.0 \\
\hline Trade in goods (f.o.b.) & 9.3 & 16.1 & 18.6 & 18.4 & 17.5 \\
\hline Services & -0.6 & -1.5 & -1.8 & -2.7 & -3.8 \\
\hline Transportation & 0.6 & 0.1 & 0.2 & 0.4 & 0.6 \\
\hline Travel & -2.0 & -2.2 & -2.8 & -3.2 & -3.5 \\
\hline Other services & 0.8 & 0.5 & 0.8 & 0.1 & -0.8 \\
\hline Compensation of employees & -0.1 & -0.2 & -0.3 & -0.2 & -0.3 \\
\hline Investment income & -5.8 & -6.3 & -7.3 & -5.6 & -5.4 \\
\hline Direct investment & 2.2 & 2.9 & 3.2 & 3.3 & 3.6 \\
\hline Portfolio investment excl. fin. derivatives & -0.7 & -0.8 & -2.4 & -3.3 & -6.4 \\
\hline Income on equity & -0.1 & -0.4 & -1.0 & -0.8 & -0.7 \\
\hline Income on debt (interest) & -0.6 & -0.4 & -1.4 & -2.5 & -5.6 \\
\hline Other investment & -7.3 & -8.5 & -8.0 & -5.6 & -2.7 \\
\hline Current transfers & -1.1 & -2.6 & -2.8 & -3.2 & -3.4 \\
\hline Capital account & -1.0 & -0.5 & -0.7 & 0.0 & 0.8 \\
\hline Financial account $2 /$ & 3.8 & -2.9 & -3.6 & 2.0 & 3.0 \\
\hline Direct investment & -0.3 & 3.2 & 0.4 & -1.7 & -3.1 \\
\hline Abroad & -6.7 & -11.2 & -4.7 & -12.6 & -22.5 \\
\hline In Sweden & 6.4 & 14.5 & 5.1 & 10.9 & 19.4 \\
\hline Portfolio investment excl. fin. derivatives & -13.5 & -2.3 & -12.4 & -11.7 & -15.5 \\
\hline Assets & -2.6 & -10.6 & -13.2 & -9.2 & -17.5 \\
\hline Equity securities & -2.5 & -9.1 & -7.5 & -5.6 & -7.4 \\
\hline Debt securities & -0.1 & -1.5 & -5.7 & -3.6 & -10.1 \\
\hline Liabilities & -10.9 & 8.2 & 0.7 & -2.5 & 2.0 \\
\hline Equity securities & 6.8 & 2.0 & 4.1 & -1.7 & -0.4 \\
\hline Debt securities & -17.7 & 6.2 & -3.3 & -0.8 & 2.4 \\
\hline Financial derivatives (net) & 0.0 & -0.8 & 1.5 & 2.1 & -1.3 \\
\hline Other investment & 20.0 & -4.4 & 0.7 & 6.8 & 26.3 \\
\hline Reserve assets (increase $=-$ ) & -2.3 & 1.4 & 6.2 & 6.5 & -3.3 \\
\hline Net errors and omissions & -4.4 & -2.1 & -2.2 & -8.6 & -8.4 \\
\hline \multicolumn{6}{|l|}{ Memorandum Items: } \\
\hline Net foreign assets 3/ & $\ldots$ & $\ldots$ & $\ldots$ & -100.7 & -90.1 \\
\hline (In percent of GDP) & & & & -44.2 & -39.4 \\
\hline \multicolumn{6}{|l|}{ Official reserves } \\
\hline In weeks of imports & 22.9 & 18.3 & 15.4 & 9.0 & 11.2 \\
\hline
\end{tabular}

1/ New definitions were adopted for some items in October 1997; compatibility over time is limited. 2/ Capital and financial accounts are defined as in IFS except that reserve assets here are included in the financial account instead of being a separate item.

3/ Consistent data are available only for 1997 and 1998. 
FIGURE 3

SWEDEN

\section{LABOR MARKET DEVELOPMENTS}
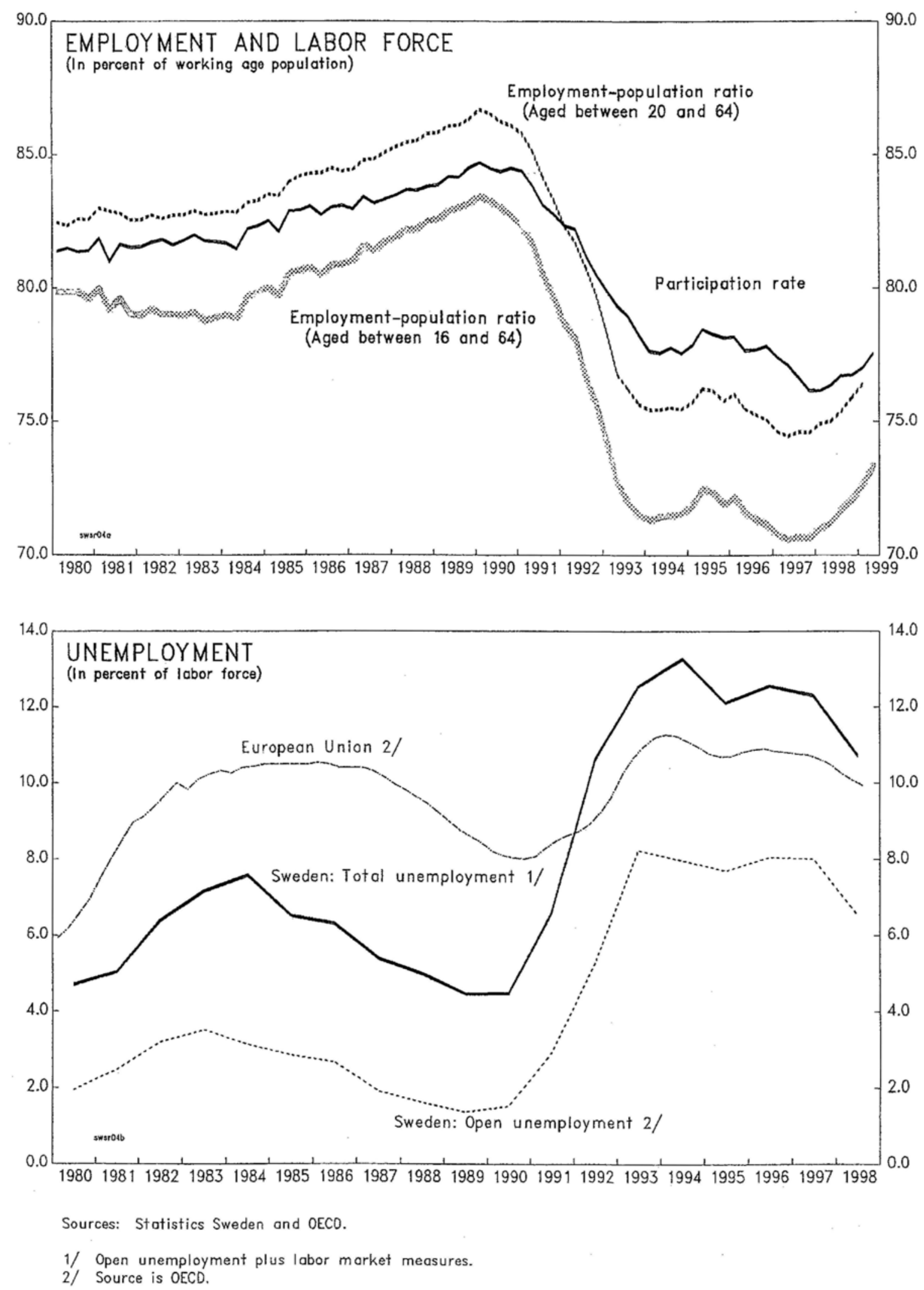
FIGURE 4

SWEDEN

INFLATION DEVELOPMENTS

(Percent change from a year ago)
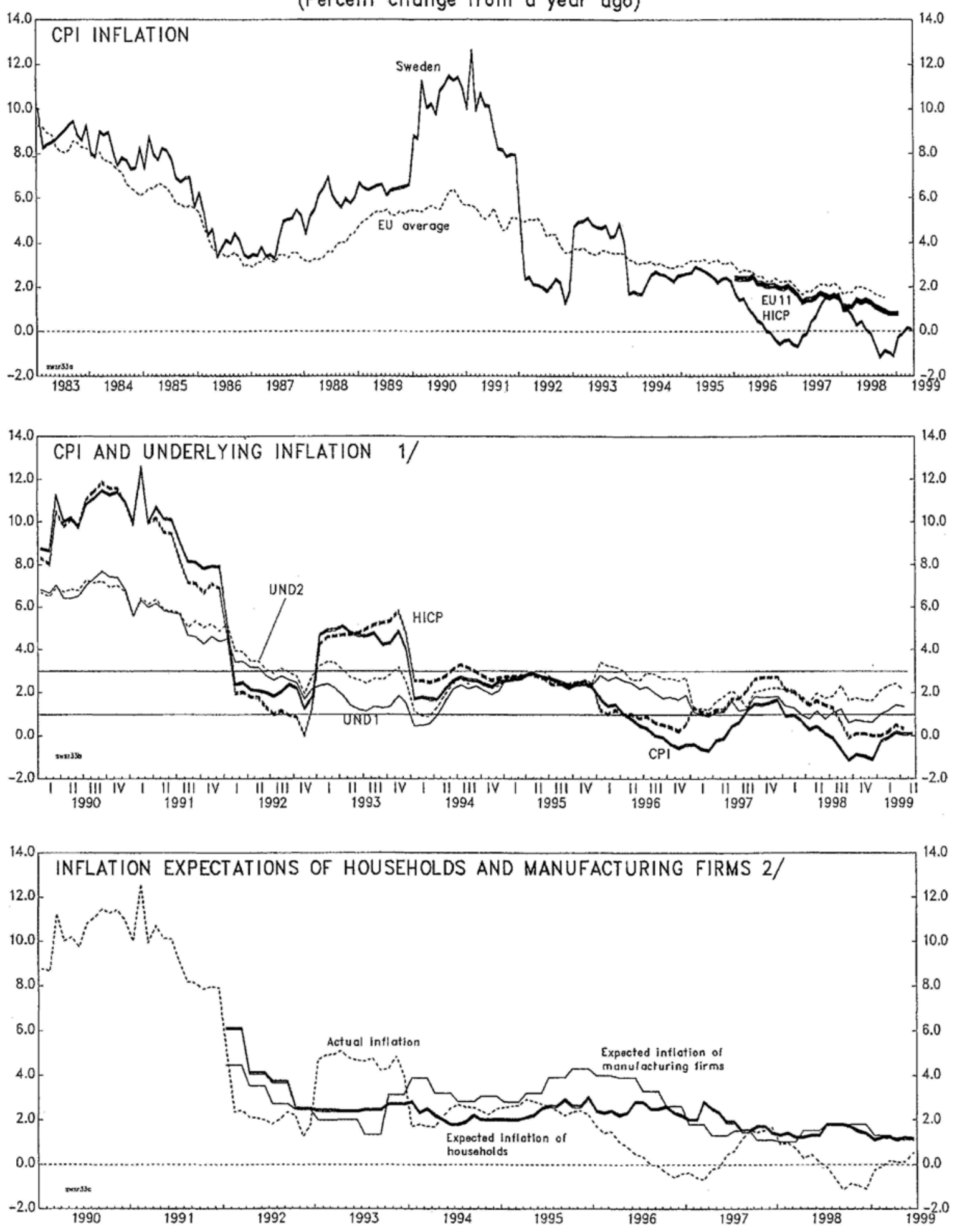

Sources: Statistics Sweden and the Riksbank.

1/ UND1 = CPI excluding changes in indirect taxes and subsidies and interest costs for owneroccupied housing; UND2 also excludes changes in import prices; the horizontal lines indicate the inflation target range, centered at $2 \%$.

2/ Inflation expected one year ahead. 


\section{Box 1. Hours Worked in Sweden}

Although the employed portion of the working-age population is relatively high in Sweden, the effect on output is offset by a relatively low number of hours worked. As shown in the table below, Sweden is in the top third of industrial countries in employment (73 percent of the working-age population in 1996) but near the bottom in annual number of hours worked (above only the Netherlands and Norway). These two factors roughly offset each other, if Sweden were at the mean in both columns, total hours worked in the economy would be nearly the same.

An important factor reducing average hours worked in Sweden is the prevalence of part-time work in service sectors, rather than a short normal work week or a shortage of overtime. The third column of figures in the table, which shows annual hours worked in industry, reveals that Sweden is close to the median for the eleven countries for which comparable data are available. In the final column, however, one sees that Sweden is well above average (ranked sixth out of twenty) in the portion of total working hours done on a part-time basis.

Wage compression and the high marginal tax burden appear to have contributed to the prevalence of part-time work in Sweden. Workers in the service sector workers may be priced out of the market because of the difficulty of linking wages to productivity. The high tax burden produced by the interaction of income, labor, and social security taxes further compounds the overpricing of services and precludes that sector from developing its full potential. As a consequence, some services provided routinely in other industrial countries, including home repairs and other household services, seem more likely to be provided off-market or through less formal channels in Sweden. In addition to widespread anecdotal evidence, this scenario is supported by a survey undertaken by Statistics Sweden in 1990/91, which revealed that total weekly hours worked (combining both paid and unpaid work) for those in the $20-64$ age range was about 60 , of which only 35 were for pay. ${ }^{1}$

\begin{tabular}{|c|c|c|c|c|}
\hline Country & $\begin{array}{l}\text { Employment - } \\
\text { Population Ratio }\end{array}$ & $\begin{array}{c}\text { Annual Hours } \\
\text { Worked (Economy- } \\
\text { wide) }\end{array}$ & $\begin{array}{c}\text { Annual Hours } \\
\text { Worked (Industry) }\end{array}$ & $\begin{array}{l}\text { Part-time Portion of } \\
\text { Total (Economy-wide) }\end{array}$ \\
\hline Australia & 68.3 & 1867 & $\ldots$ & 25.0 \\
\hline Austria & 68.1 & $\ldots$ & $\ldots$ & 14.9 \\
\hline Belgium & 56.6 & $\ldots$ & 1618 & 14.0 \\
\hline Canada & 68.5 & 1732 & 1966 & 18.9 \\
\hline Denmark & 74.7 & $\ldots$ & 1575 & 21.5 \\
\hline Finland & 62.2 & 1790 & $\ldots$ & 8.0 \\
\hline France & 59.6 & 1645 & 1642 & 16.0 \\
\hline Germany $^{2}$ & 64.0 & 1578 & 1513 & 16.3 \\
\hline Iceland & 84.8 & $\ldots$ & $\ldots$ & 27.9 \\
\hline Ireland & 56.2 & $\ldots$ & $\ldots$ & 11.6 \\
\hline Italy $^{3}$ & 51.3 & 1682 & 1797 & 6.6 \\
\hline Japan $^{3}$ & 74.6 & 1898 & 1978 & 21.4 \\
\hline Netherlands & 66.0 & 1372 & 1602 & 36.5 \\
\hline Norway & 76.8 & 1410 & $\ldots$ & 26.5 \\
\hline Portugal & 67.2 & 2009 & $\ldots$ & 10.6 \\
\hline Spain & 48.1 & 1810 & $\ldots$ & 8.0 \\
\hline Sweden & 72.7 & 1554 & 1641 & 23.6 \\
\hline Switzerland ${ }^{3}$ & 76.1 & 1643 & $\ldots$ & 27.4 \\
\hline United Kingdom & 71.0 & 1732 & 1848 & 22.1 \\
\hline United States & 75.0 & 1951 & 1986 & 18.3 \\
\hline \multicolumn{5}{|l|}{$\begin{array}{l}\text { Averages (unweighted } \\
\text { means) }\end{array}$} \\
\hline EU members & 62.9 & 1686 & 1655 & 16.1 \\
\hline All countries & 67.1 & 1712 & 1742 & 18.8 \\
\hline
\end{tabular}

Sources: U.S. Dept. of Labor 1998; OECD Employment Outlook 1997. Except as noted, data are for 1996 (economy-wide) or 1997 (industry).

${ }^{1}$ M. Henrekson, "Higher Employment through Developing the Market Sector," Ekonomist Debatt 1998, Volume 26, No. 7.

${ }^{2}$ Data on the part-time portion are for 1995.

${ }^{3}$ Data for hours worked are for 1994 or 1995. 
a reflection of the weakness of the euro, but it also may be linked to expectations of an eventual EMU entry at a more appreciated exchange rate level. ${ }^{7}$ Over the medium term, the strong external position is expected to continue to support the value of the currency.

\section{Long-term interest rates have fallen to levels that are close to those in the euro} area. From a peak of about 5 percentage points in mid-1994, the differential over long-term rates in Germany fell to about 40 basis points in mid-1998 (Figure 6). Although it rose during the turbulence of last autumn, it subsequently returned to that low level. The nominal differential is greater than the 16 basis-point average differential over German rates within the euro area, and the real differential is somewhat higher. Even so, the differential is small enough that the risk premium from remaining outside the euro area appears now to be fairly low.

11. Favorable macroeconomic conditions are contributing to the further strengthening of the Swedish financial system, while the effects of financial market difficulties internationally have been mild. Profitability and capital adequacy for banks and other major financial institutions remain sound. ${ }^{8}$ The exposure of Swedish banks to the troubled regions of Latin America, Russia, and East Asia is limited; those countries account for only about 5 percent of Swedish bank loans to nonresidents. Trade links with these regions are also modest, accounting for about 10 percent of Swedish exports and about 5 percent of Sweden's foreign direct investment. It appears that the largest risk to Swedish banks from international problem regions arises indirectly, from wholesale market exposure to banks in the United States and Western Europe. More generally, the financial position of the economy seems strong. Although household saving is low, ratios of household debt and interest expenditure to disposable income are at historically low levels, as are ratios of corporate debt to equity. Bankruptcies have continued to decline. Equity and property market prices have accelerated in the past year, but those increases have not yet appeared to be unsustainable or inconsistent with fundamental conditions. ${ }^{9}$

${ }^{7}$ In early January, following the nouncement of a specially convened congress of the main ruling party (the SDP) in the spring of 2000 to discuss the issue of EMU entry, the krona strengthened sharply. Subsequently, as public and governmental support for entry waned, the currency weakened.

${ }^{8}$ The four large banking groups in Sweden each reported a return on own funds in excess of 10 percent for 1998 , with an average return of around 20 percent. The banks' capital ratios have declined in recent years as a result of expanded lending, but they are still above 10 percent.

${ }^{9}$ Price-earnings ratios for Swedish companies are not high relative to those in other industrial countries, and office occupancy rates are not low. Much of the rise in asset prices can be explained by declines in real interest rates in combination with increases in real rental rates. This evaluation does not imply that Sweden would be invulnerable to a significant international downturn in equity markets. For further analysis of the financial system, see Chapter IV in "Sweden-Selected Issues" (August 1999). 
FIGURE 5

SWEDEN

\section{EXCHANGE RATE DEVELOPMENTS}
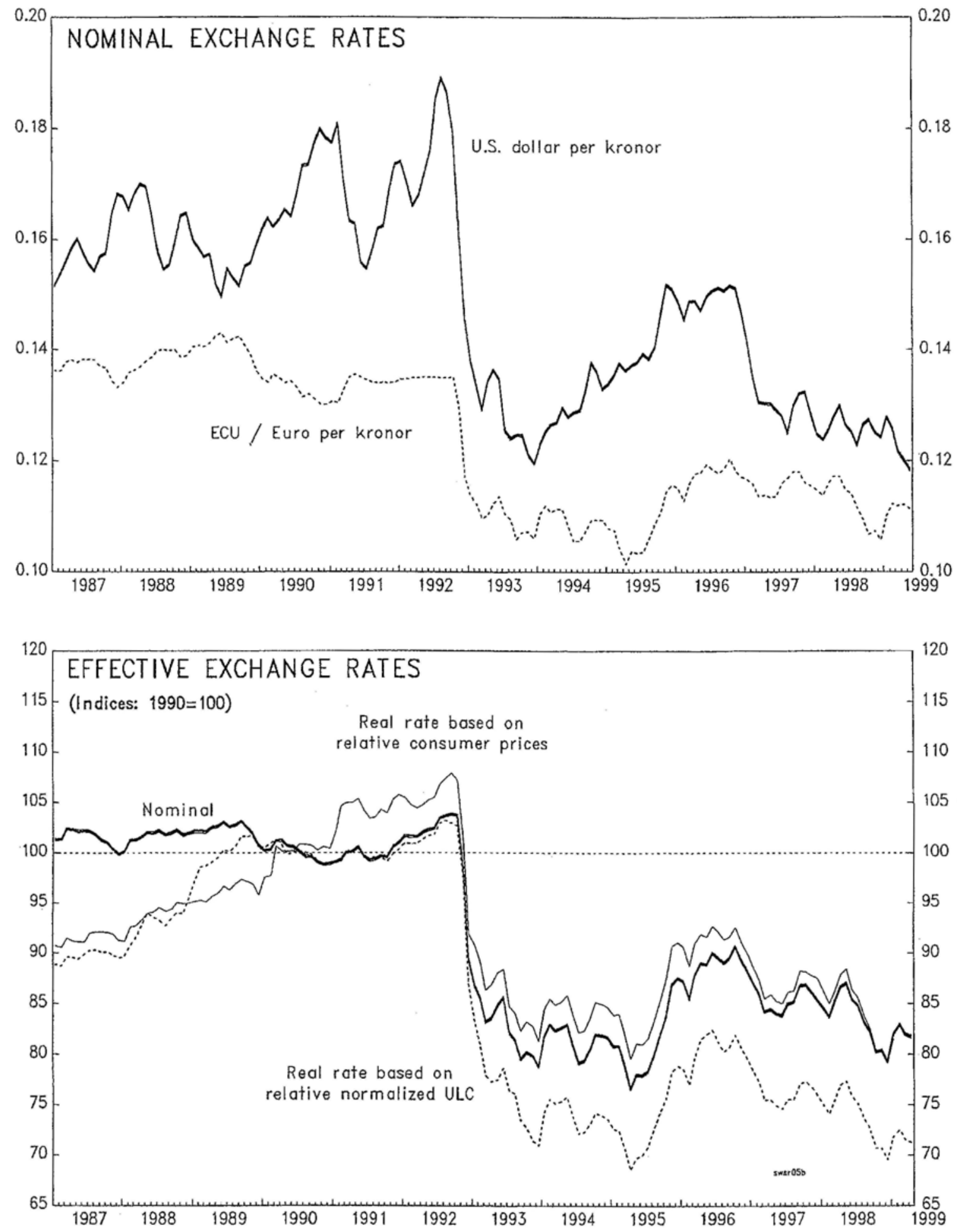

Source: IMF, Internationai Financial Statistics. 
FIGURE 6

SWEDEN

INTEREST RATE DEVELOPMENTS
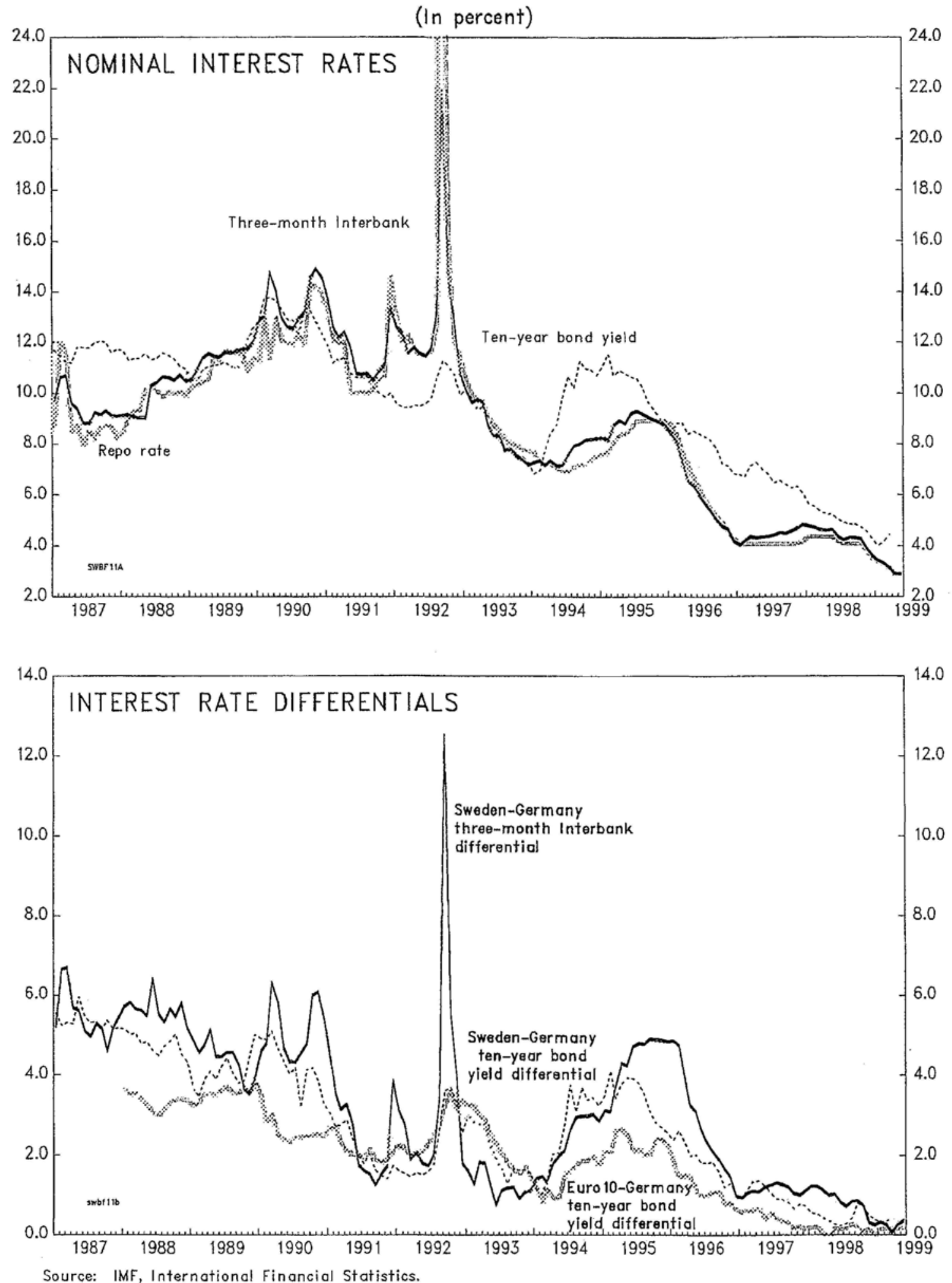


\section{Policies}

12. Fiscal adjustment has been dramatic since the implementation of the consolidation program in 1994, but government expenditure and taxation remain high relative to other industrial countries. Adjusted for cyclical effects, the ratio of government consumption and investment spending to GDP was reduced by 13/4 percentage points from 1994 to 1998 , and cuts in transfers to households reduced the overall spending ratio by another $3 \frac{3}{4}$ points. Taking account of tax increases and reduced interest costs, the overall structural improvement amounted to some 10 percentage points and produced a fiscal surplus of 2.2 percent in 1998 (Table 4 and Figure 7). Even so, total government expenditure and taxation account for well over half of GDP and are far above the industrial-country average. ${ }^{10}$ Looking ahead, the Government has established ceilings on central government spending that should reduce the expenditure ratio for general government by another 5 percentage points by $2002 .{ }^{11}$ Expenditure control is being reinforced by a comprehensive reform of the old-age pension system (Box 2) and supplemented by a nascent program of restructuring and privatizing public-sector enterprises. These policies are expected to reduce consolidated gross debt from 75 percent of GDP in 1998 to 51 percent in 2002, while net debt falls from 15 percent to zero.

\section{The Riksbank has successfully implemented monetary policy in a forward-} looking inflation targeting framework for six years, though its track record is still being debated. It has frequently undershot its inflation target (specified as a range of 1 to 3 percent), and some critics have concluded that monetary policy is biased against lowering interest rates. The Riksbank has, however, made numerous rate reductions since 1996, and the standard measures of underlying inflation have generally stayed in or close to the target range (Table 1 and Figure 4). The most recent cut in the repo rate- to 2.9 percent on March 25-took it below the comparable euro rate for two weeks, until the ECB cut its rate to 2.5 percent. In an attempt to clarify its policy, the Riksbank announced earlier this year that it regards departures from the inflation target as warranted if the CPI is affected by temporary factors such as changes in interest expenditure, indirect taxes, and subsidies, or if a quick return to the target in the event of a sizeable deviation would be too costly for the

${ }^{10}$ In 1996, the average tax burden in OECD member countries was 37 percent of GDP. The figure for Sweden was 50 percent. Source: OECD, Revenue Statistics 1997.

${ }^{11}$ The ceilings have been set annually since 1997 for the current and next three fiscal years, only for the central government. So far, these ceilings-which have been met in each year's outturn - have allowed central government spending (including social security) to rise at an average annual rate of 2 percent. The ceilings for 2000-2002 imply a nominal growth rate of $2 \frac{1}{2}$ percent. 
Table 4. Sweden: General Government Finances 1/

(In percent of GDP)

\begin{tabular}{|c|c|c|c|c|c|c|c|}
\hline & 1994 & 1995 & 1996 & 1997 & 1998 & 1999 & 2000 \\
\hline Revenue & 59.7 & 59.2 & 63.7 & 62.8 & 64.6 & 63.9 & 62.6 \\
\hline Taxes and contributions & 49.9 & 49.9 & 54.1 & 54.2 & 56.1 & 56.0 & 55.2 \\
\hline Interest & 5.8 & 5.8 & 5.5 & 4.9 & 4.6 & 4.0 & 3.6 \\
\hline Other & 4.1 & 3.9 & 4.1 & 3.7 & 3.9 & 3.9 & 3.8 \\
\hline Expenditure & 70.0 & 67.3 & 65.8 & 63.9 & 62.4 & 62.1 & 60.5 \\
\hline Transfers & 32.8 & 31.4 & 30.3 & 29.1 & 28.6 & 28.3 & 27.2 \\
\hline Consumption and Investment & 30.2 & 30.7 & 28.2 & 28.2 & 28.0 & 28.7 & 28.8 \\
\hline Interest & 6.8 & 7.1 & 7.2 & 6.6 & 5.8 & 5.2 & 4.5 \\
\hline Financial balance & -10.3 & -7.8 & -2.1 & -1.1 & 2.2 & 1.8 & 2.1 \\
\hline Structural balance $1 /$ & -6.6 & -5.9 & 0.3 & 1.4 & 4.0 & 3.7 & 3.5 \\
\hline Primary balance $2 /$ & -9.5 & -6.5 & -0.4 & 0.6 & 3.4 & 3.0 & 3.0 \\
\hline Structural primary balance $1 /$ & -5.8 & -4.6 & 2.0 & 3.1 & 5.2 & 4.9 & 4.4 \\
\hline Gross consolidated debt & 79.3 & 78.0 & 77.2 & 77.0 & 75.4 & 67.6 & 62.2 \\
\hline \multicolumn{8}{|l|}{ Memorandum item: } \\
\hline Privatization receipts & $\ldots$ & 0.5 & 0.3 & 0.9 & 0.6 & 2.4 & 2.3 \\
\hline Output gap & -4.1 & -2.1 & -2.7 & -2.8 & -2.2 & -1.7 & -1.0 \\
\hline
\end{tabular}

Sources: Ministry of Finance; National Institute of Economic Research; and staff calculations.

1/ The elasticity of the financial balance with respect to the output gap is taken to be 0.9 .

2/ Excludes interest revenue and expenditure. 
FIGURE 7

SWEDEN

\section{FISCAL DEVELOPMENTS AND PROSPECTS}
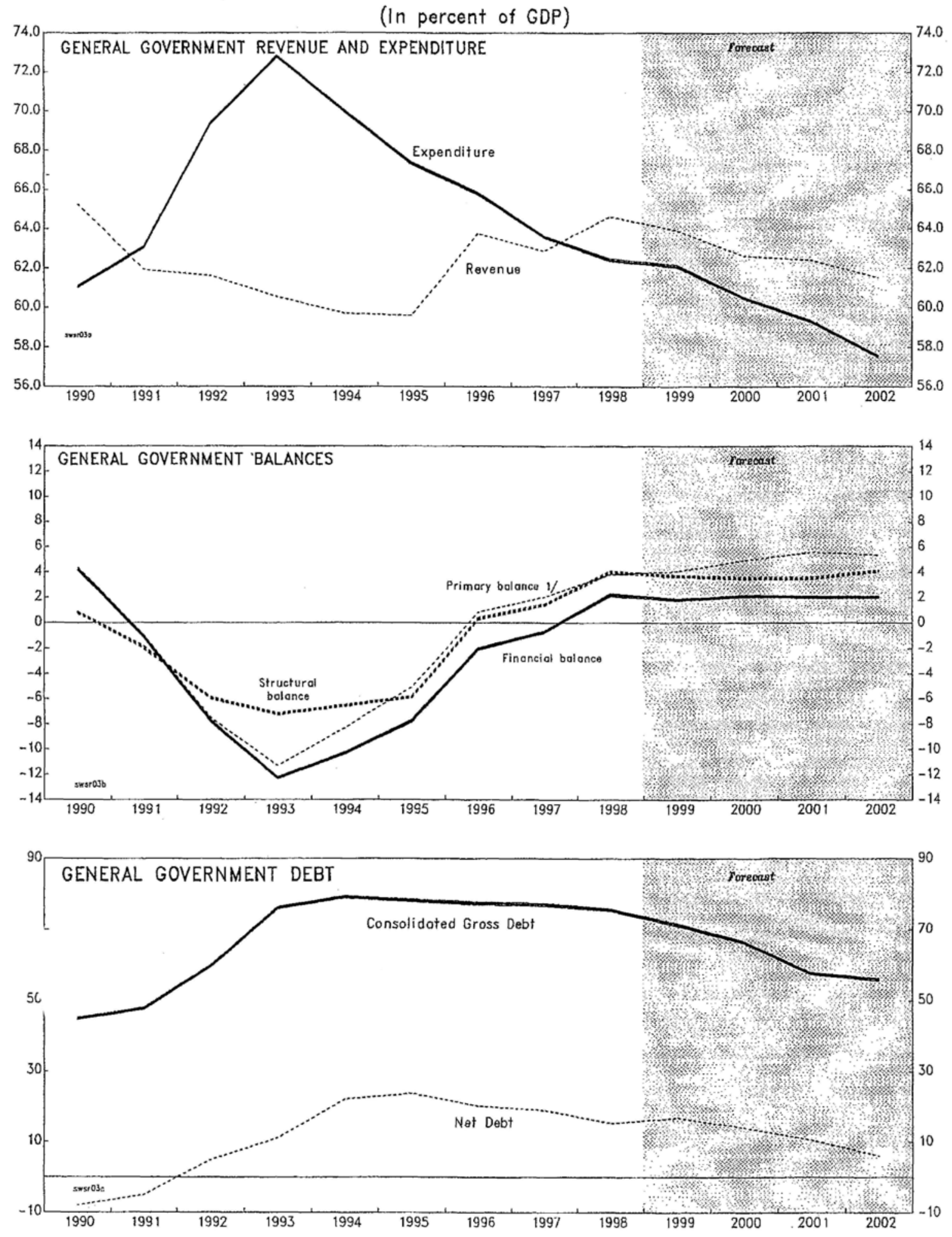

Sources: Statistics Sweden and Ministry of Finance.

1) Excluding interest expenditure and income. 


\section{Box 2. Pension Reform}

In 1998, the Parliament agreed in principle to implement a far-reaching reform of the pension system, aimed at linking benefits more closely to contributions, ensuring the longrun solvency of the system as demographic shifts place increasing strains on it, and introducing additional flexibility into retirement options.

The current system, which has been in effect since the early 1960s, provides defined-benefit pensions linked to previous earned income for virtually all residents with work experience in Sweden, financed on a "pay-as-you-go" basis through a fixed rate of contributions from employers. These pensions, which are indexed to the cost of living, supplement a "basic pension" available to all residents regardless of work experience or income level. Until now, excess contributions over payments have produced a National Pension Fund (NPF) equivalent to around 40 percent of GDP. Without some modification, however, demographic simulations suggest that the NPF would be exhausted by 2020 .

The new system, which is to take effect in 2001 , will retain the current financing scheme with a fixed contribution rate of 18.5 percent of salaries. Most of the contributions (16 percentage points) will be credited to a notional personal account that will finance a pension annuity, the value of which will be actuarially determined at the time of retirement and indexed to the wage bill rather than the CPI. The rest ( 2.5 percentage points) will be placed in an individually managed investment account; workers thus will gain a measure of control over the risk-return tradeoff in preparing for retirement. Older workers will continue to be covered primarily under the current rules, younger ones will be transferred immediately to the new system, and a gradual transition is planned for those in the middle. Restrictions on part-time work by pensioners will be relaxed.

Because of the increased actuarial linkage and the shifting of future social security revenues into the NPF instead of general revenues, roughly half of the existing NPF can be liquidated and will be used to retire government debt. The remainder (equaling some 20 percent of GDP) will serve as a buffer to absorb the costs of large cohorts. To further secure the financial stability of the system, a trigger mechanism is being developed to reduce the indexation formula if economic growth or investment returns turn out lower than expected or life expectancy turns out to be higher.

For further information, see Chapter IV in "Sweden—Selected Issues" (SM/98/223; September 2, 1998). 
economy in the short-term. It also announced that it would indicate in advance the magnitude of any deviation to be tolerated.

14. Riksbank credibility was enhanced further at the beginning of this year by the implementation of legislation granting the bank increased independence and by the consequent selection of a new and more independent Executive Board. The previous Governing Board was composed of political representatives in proportion to party strength in parliament. The new Executive Board consists of six members appointed for six-year terms (ranging initially from one to six years), is chaired by the Governor of the Riksbank, has a mandate to pursue price stability, and can make policy decisions without prior Government consent. Parliamentary oversight is accomplished through the election of a Governing Council (which appoints the Governor and other members of the Executive Board) and through semi-annual presentations by the Governor to the Standing Committee on Finance, in response to which the Committee will report its own evaluation of the policy process and outcome. The Executive Board holds about 8-10 monetary policy meetings during the year and publishes its minutes within 6-8 weeks.

\section{In 1997, the Government established a commission to recommend improvements} to the wage negotiation process. The motivation for the Öberg Commission derived from the poor performance of wage formation over the past twenty years when excessive wage agreements were offset by periodic exchange rate adjustments to maintain Swedish competitiveness. ${ }^{12}$ In November 1998, the commission issued its report, which included several laudable recommendations. Specifically, it proposed establishing a new Mediation Authority to strengthen the infrastructure of wage negotiations. In addition, the commission proposed extending the period of notice for industrial action from 7 to 14 days, limiting the right of unions to take sympathetic industrial action, and making unions pay the associated costs of such actions. The report did not present a view on the relative merits of centralized versus decentralized negotiations. None of the key recommendations has yet been implemented.

\section{Outlook}

\section{In the revised budget presented in April, the authorities projected GDP growth} to slow to 2.2 percent in 1999 and then to rise to $2 \frac{1}{2}$ percent over the medium term. In this scenario, growth would become more balanced, with slower domestic demand growth (especially on fixed investment) offset partly by a return to positive levels of net exports. The output gap would be eliminated by 2002 . Assuming that wage growth did not drift upward, the authorities projected that employment growth would maintain its recent momentum and

\footnotetext{
${ }^{12}$ In the mid-1970s, significant wage increases were triggered by imported price increases in connection with worldwide inflation and by increases in payroll taxes. As a result, the growth of product real wages far outpaced the growth of labor productivity, which required several devaluations to restore competitiveness. See Chapter II in "Sweden-Selected Issues," SM/98/223 (September 2, 1998).
} 
average about 1 percent per annum. The employment-population ratio would rise to $761 / 2$ percent by 2002 , and the open unemployment rate would decline to 5 percent. The anticipated strengthening of the krona would help to offset the inflationary consequences of this advancing cyclical position. ${ }^{13}$

\section{Since the publication of the authorities' forecast, activity indicators have} exceeded expectations. New orders and production in the manufacturing and construction sectors are up sharply, and retail sales and employment in business services continue to grow rapidly. Incorporating these effects into the forecast, the staff expects yearly growth to average around $23 / 4$ percent over the next three years, trending down to 2.2 percent in 2002 when the economy will be at full capacity. ${ }^{14}$ This forecast is based on moderate growth in Europe this year and next ( 2 and 2.9 percent respectively), without which the contribution from export growth would be diminished; and on continued adherence to sound fiscal policies, without which inflationary pressures could resume and force an increase in interest rates from their present low level.

\section{REPORT ON THE DISCUSSIONS}

18. The discussions focused on two major topics: the objectives and stance of fiscal and monetary policies, ana the prospects for further structural reform. On fiscal policy, the discussion examined the Government's objective of a 2 percent fiscal surplus over the cycle and the extent to which future tax reductions were consistent with this target. On monetary policy, the focus was on the experience with inflation targeting and with the new Riksbank legislation. The main structural issues concerned the efficiency of the labor market, where distortionary taxes and an outmoded wage bargaining process appear to be limiting the productive capacity of the economy and delaying the transition to non-inflationary, employment-generating growth.

\section{A. Fiscal Policy}

\section{The authorities emphasized that restoring confidence in the soundness of} government finances had been the central aim of fiscal policy since the current

\footnotetext{
${ }^{13}$ The authorities have estimated that a 10 percent appreciation of the krona would reduce the CPI by $1 / 2$ percent within one year and by 2 percent over the long term (including indirect effects).

${ }^{14}$ Staff analysis indicates that the decline in the fiscal expenditure ratio over the past few years has added 0.3 percentage point per annum to total factor productivity growth, raising potential output growth from 1.9 percent to 2.2 percent. Potential growth is projected to remain at 2.2 percent through 2002 , at which point, as government spending stabilizes in relation to GDP, it should revert to the earlier estimate. See Chapter II in "Sweden-Selected Issues" (August 1999).
} 
administration had taken office in the latter part of 1994. To accomplish this objective, the Government had adopted a strong program of fiscal adjustment in 1994-95-the Consolidation Program - which aimed to narrow the fiscal deficit to less than 3 percent of GDP in 1997 and to achieve balance in 1998. In addition, the Government had announced in 1996 that it would introduce rolling three-year expenditure ceilings, and the following year it had adopted a target for the a general government fiscal surplus of 2 percent of GDP on average over the economic cycle. The surplus target was aimed at ensuring that Sweden would meet the demands of the EU Stability and Growth Pact and could eliminate net government debt by 2010 (currently 15 percent of GDP), so as to pave the way for meeting rising pension claims in the next century. ${ }^{15}$

20. These fiscal objectives had been surpassed, and the stage was set for resources to be returned to households in future years while maintaining the surplus target. With a fiscal surplus of more than 2 percent of GDP in 1998 and close to that level again in 1999, the Government had gained significant room for maneuver. Under current policies, the fiscal position was projected to strengthen further over the medium term, to surpluses of 3-4 percent in 2001 and 2002, which would generate room for up to 1-2 percent of GDP to be returned to households in both years. ${ }^{16}$ The Government did not yet have a detailed plan for these transfers, but the authorities indicated that lowering the income tax burden of lowand middle-income earners would have priority.

\section{The staff expressed support for targeting a structural fiscal surplus of 2 percent}

of GDP. Although the target was ambitious, it was necessary both to create room for automatic stabilizers to work without compromising the conditions of the Stability and Growth Pact and to relieve monetary policy of some of the burden of controlling domestic demand. The staff underlined that the fiscal target was dependent on the cyclical position of the economy and should be regarded as an average rather than a ceiling. If strong growth

${ }^{15}$ The Stability and Growth Pact obliges EU member countries to limit fiscal deficits to no more than 3 percent of GDP and to aim for stronger budget positions so as to avoid slippages except in conditions of severe recession. Various studies, including those of the staff, suggest that a 1 percentage point deterioration in Sweden's output gap raises the fiscal deficit by $3 / 4$ to 1 percentage point of GDP. (See Chapter I of "Sweden-Selected Issues," SM/97/205, August 7,1997 .) Starting from a 2 percent fiscal surplus and assuming potential output growth of around 2 percent, real GDP could decline by 1 to 2 percentage points over two years without breaching the deficit limit.

${ }^{16}$ As the Swedish authorities do not report estimates for the cyclically adjusted fiscal position, analysis of the actual surplus is complicated. Under the authorities' assumptions, full employment will not be achieved until 2002. The structural surplus (the fiscal target variable) would therefore be at least as large as the actual surplus until that time. The implied target for the actual surplus thus would be no more than 2 percent of GDP in both years. 
were to push output above its potential level, as seemed likely by 2002 , the surplus would have to rise above 2 percent to be compatible with the Government's objective.

22. Given the high revenue and expenditure ratios to GDP in Sweden and the current strength of the economy, the staff suggested that the time was ripe for consideration of a broadly based fiscal reform. The Government's plan to return income to households over the medium term, taken by itself, ran the risk of further fueling demand while the economy might already be overheating. That risk, however, had to be seen in light of the desirability of improving economic efficiency. Adhering strictly to the announced path for government spending - and making additional cuts as soon as possible - would help resolve this potential conflict between demand management and structural reform.

\section{Differences in view between the staff and the authorities on fiscal reform} centered on priorities and political realities rather than on fundamentals. The authorities stressed their intention to adhere to the expenditure ceilings, which symbolized their hardearned commitment to fiscal prudence. The authorities and the staff also agreed that reducing the high tax wedges between the cost of labor and take-home pay could improve labor market performance. While the authorities placed a high priority on cutting tax rates for lowand middle-income households, particularly in light of the very low income tax threshold of about SKr 9000 (just over US\$1000) per annum, the staff noted that high tax rates at upper income levels created disincentives to work and were also out of line internationally (Box 3). ${ }^{17}$ Moreover, practices such as wealth taxation and the double taxation of dividends were contributing to inefficiencies and tax avoidance. ${ }^{18}$ In the staff view, a broader plan for tax reform over the medium term should provide a better balance between considerations of equity and economic efficiency.

\section{B. Monetary Policy}

24. Riksbank officials argued that monetary policy conditions were now fairly well balanced. As inflationary pressures remained subdued both domestically and abroad, the

${ }^{17}$ In 1995 the Government imposed a 5 percent surtax on incomes above $\mathrm{SKr} 204,000$ (around US\$29,000). Although the initial intention was to abolish this tax on January 1, 1999 , the Government chose instead to raise the threshold to SKr 360,000 (US\$43,000).

${ }^{18}$ A number of important firms have moved their head offices out of Sweden in recent years. Although some of these moves could be rationalized in terms of closer access to a larger market, such as the relocation of Astra-Zeneka (pharmaceuticals) to London, other moves such as the departure of MeritaNordbanken (banking) and Stora-Enso (forestry) to Finland were probably influenced by the more favorable capital taxation regime in Finland. 


\section{Box 3. Labor and Capital Taxes in Selected Industrial Countries}

Among industrial countries, Sweden stands out as having the second highest marginal tax rate on labor income (after Denmark) and one of the highest tax rates on dividends, capital gains, and wealth. As a result, employment prospects are hindered, and small new firms have limited incentives to expand. Substantial tax cuts on both labor and capital incomes would be needed to bring Sweden into line with the majority of industrial countries.

\begin{tabular}{|c|c|c|c|c|c|c|}
\hline \multicolumn{3}{|c|}{ Labor Income Taxes } & \multicolumn{4}{|c|}{ Capital Income Taxes } \\
\hline Country & $\begin{array}{l}\text { Tax exempt } \\
\text { income } \\
\text { (US } \$ 000) \\
\end{array}$ & $\begin{array}{c}\text { Marginal tax } \\
1 / \\
\text { (percent) }\end{array}$ & $\begin{array}{c}\text { Dividends } 2 / \\
\text { (percent) }\end{array}$ & $\begin{array}{c}\text { Capital gains } \\
\text { (percent) }\end{array}$ & $\begin{array}{l}\text { Wealth tax } \\
\text { rate (percent) }\end{array}$ & $\begin{array}{l}\text { Wealth tax } \\
\text { Threshold 3/ } \\
\text { (US\$000) }\end{array}$ \\
\hline Austria & 5.4 & 22 & 50 & 0 & 0 & \\
\hline Belgium & 5.6 & 25 & 49 & 0 & 0 & \\
\hline Denmark & 4.6 & 45.2 & 60 & 40 & 0 & \\
\hline Finland & 1.6 & 17 & 28 & 28 & 0.9 & 205 \\
\hline France & 4.3 & 18 & 66 & 26 & $0.5-1.5$ & 775 \\
\hline Germany & 7.0 & 22 & 49 & 0 & 0 & \\
\hline Ireland & 5.7 & 26 & 55 & 40 & 0 & \\
\hline Netherlands & 4.3 & 36.4 & 74 & 0 & 0.7 & 96 \\
\hline Norway & 3.3 & 28 & 28 & 28 & $0.7-1.1$ & 20 \\
\hline Sweden & 1.1 & 36.4 & 49.6 & 30 & 1.5 & 112 \\
\hline $\begin{array}{l}\text { United } \\
\text { Kingdom }\end{array}$ & 6.7 & 20 & 48 & $0-40$ & 0 & \\
\hline $\begin{array}{l}\text { United } \\
\text { States }\end{array}$ & 7.1 & 19 & 68 & $0-20$ & 0 & \\
\hline $\begin{array}{l}\text { Sources: OE } \\
\text { Research on } \\
\text { 1/ First tax b } \\
\text { 2/ Taxation } \\
\text { 3/ Minimum }\end{array}$ & $\begin{array}{l}\text { Krister Ander } \\
\text { opean Econon } \\
\text { ket above the t } \\
\text { oth corporate a } \\
\text { alth level subj }\end{array}$ & $\begin{array}{l}\text { son (1998) "EM } \\
\text { cs, Law and Go } \\
\text {-free threshold } \\
\text { d investor level } \\
\text { t to tax. }\end{array}$ & $\begin{array}{l}\mathrm{U} \text { and Our Fut } \\
\text { ernment, and s } \\
\text { at both the fede }\end{array}$ & $\begin{array}{l}\text { Taxes," in Eur } \\
\text { aff calculations. } \\
\text { al and local leve }\end{array}$ & $\begin{array}{l}\text { opean Perspect } \\
\text { Data are for } 19\end{array}$ & s, Yearbook of \\
\hline
\end{tabular}


Riksbank had reduced the repo rate by 120 basis points since mid-1998. At least for the moment, however, interest rate cuts seemed to be over. As reported in the Riksbank's June 1999 inflation report, the bank is projecting — on the basis of an unchanged repo rate - that CPI inflation will rise to 1.6 percent in two years, while the underlying rate (which excludes the effects of mortgage interest costs, indirect taxes, and subsidies) will rise to 2 percent: the mid-point of the inflation target range. ${ }^{19}$ The staff concurred that the current policy stance was broadly appropriate.

\section{Officials acknowledged that explaining the continued undershooting of the} inflation target in terms of temporary influences had become a real challenge, especially because those influences had acted persistently in one direction for more than three years. That challenge had motivated the publication of the new monetary policy guidelines earlier this year, but the situation remained unsatisfactory. The central problems are that changes in indirect taxes, import prices, and other transitory influences are having persistent effects; and that cuts in interest rates have the perverse effect of reducing CPI inflation in the short term. Pending the results of ongoing work on defining a preferred alternative to the CPI, the Riksbank was delaying a switch to an index of underlying inflation. One option under consideration was the EU's Harmonized Index of Consumer Prices (HICP), but the EU was still in the process of finalizing the composition of the index. Moreover, the HICP as presently defined did not adjust for the effects of changes in indirect taxes and therefore had also moved outside the target range for some time (Figure 4). While acknowledging the valid reasons for delaying implementation of a new inflation target, the staff recommended that such a shift be made as soon as possible to minimize unnecessary controversies about the policy stance.

\section{Political criticism of Riksbank policy was reflected in the first semi-annual} report issued in late May by the parliamentary Standing Committee on Finance. In the report, the Committee argued that the Riksbank had been too slow to lower interest rates in 1996 and again in early 1998. The staff, however, concurred with the Riksbank's argument that the credibility of Sweden's macroeconomic policies had remained uncertain in 1996 and that the extent of the fallout from the financial crisis in East Asia had remained uncertain in early 1998. The staff suggested that the transparency of the policy process could be enhanced through an independent external review by monetary policy experts to assess performance and public accountability.

27. The authorities noted that EMU membership was still being debated and that the lack of clear public support support might make accession at the beginning of 2002 less than

${ }^{19}$ Inflationary tendencies are evaluated by the Riksbank by forecasting over a horizon of 12 to 24 months. The policy goal may be described as to nudge inflation toward the target level over that horizon, taking into account the costs of large sudden changes in interest rates and the inevitable lags in response to policy changes. 
likely. ${ }^{20}$ This uncertainty had contributed to the weakening of the currency in the spring, but officials at the Riksbank continued to project that the krona would strengthen somewhat over the medium term in line with estimates of the equilibrium exchange rate. ${ }^{21}$ While tactical and technical changes would accompany the shift from an inflation target to an exchange rate target once the EMU entry rate was chosen, the authorities did not think that the current broad monetary strategy would change significantly. The staff noted that Sweden's macroeconomic policies were generally in line with the rest of Europe and that the structure of the economy and of international trade were not markedly different from the current EMU members. Provided that stable policies are maintained and that the reform process discussed below is pursued, accession to EMU should be possible without the need for significant changes to the thrust of macroeconomic policy.

\section{Structural Policies}

\section{The labor market}

\section{The authorities recognized the need for further reform of the labor market and} were addressing deficiencies in two ways: first, by improving training and education to lift competence to levels that fit the narrow wage structure, and second by following up on the recommendations of the Öberg Commission on wage formation ( $\ 15)$. From 1996 to 1998 the number of fully-subsidized places in the Adult Education Effort was increased by 50 percent, targeted mainly at those unemployed with formal qualifications below a complete upper secondary education. A first provisional overview showed a marked reduction in unemployment two years later among those entering the program in 1997, but the decline was attributable mainly to increased time in the education system rather than to increased employment opportunities. The authorities indicated that the basic schooling offered to these individuals was an initial stepping stone in providing the skills needed to reenter the workforce and acknowledged that supplementing these skills with targeted work-related training would be beneficial.

29. The staff agreed that measures to improve human capital formation were well placed but argued that these measures would be insufficient on their own to generate rapid employment growth. The staff encouraged the authorities to supplement education programs with other measures to improve the supply of and demand for labor. Such measures include lowering the taxation component of labor costs, lowering replacement rates for the unemployed, and tightening eligibility requirements for unemployment benefits and shortening their effective duration.

${ }^{20}$ For an analysis of costs and benefits of EMU membership for Sweden, see Chapter III of "Sweden-Selected Issues," SM/97/205.

${ }^{21}$ The staff concurred with the Riksbank estimate that the trade-weighted effective exchange rate of the krona was perhaps 5 to 10 percent below the central point of its estimated equilibrium range. 
30. The staff underscored that numerous labor income taxes were piled on top of each other until the cost of employing workers was a large multiple of take-home pay. ${ }^{22}$ As a result of that tax structure and the compression of wage levels, entry-level and lowerskilled workers found employment especially difficult to obtain. As public-sector employment declined in the 1990 s, these factors limited the ability of the private sector to absorb the displaced workers, and unemployment had become entrenched at a high level. Moreover, unemployment benefits replaced too high a portion of lost wages and offered too many loopholes and too few incentives to get the unemployed back to work. Lowering the replacement rate from the current level of 80 percent and tightening eligibility requirements would foster stronger labor market attachment and discourage dependency on social programs. The authorities responded that the high replacement rate was a matter of social choice and that the monitoring of eligibility requirements for unemployment insurance was being studied with the aim of issuing a report in the fall.

\section{While the open unemployment rate had fallen rapidly in recent years, labor} market programs remained extensive and weekly hours worked remained low. The staff questioned the usefulness of labor market programs covering such a large portion of the labor force, especially in light of the fact that the international literature had indicated that such programs were usually ineffective. The authorities acknowledged that the extent of active labor market programs in Sweden was excessive and noted that this concern had motivated a reduction in the number of positions on offer this year. In addition, while participants with recruitment subsidies were more likely than those in a control group to gain regular employment within a year after the termination of a program, the authorities recognized that dead-weight effects were clearly present. They were less concerned with the low average level of hours worked per week, since Sweden's statistics in this area were comparable to other EU members (though not to other industrial countries).

\section{Prospects for implementing the recommendations of the Öberg Commission} appeared slight. The unions were unwilling to accept any decentralization of wage bargaining or new limitations on the right to take sympathetic industrial action, while the employers federation was resisting any move toward greater centralization. The mission argued that the current system based on industry-level agreements could be improved through greater decentralization, which would promote more extensive and more rational wage differentiation. If decentralization was not politically feasible, then even a move toward centralization would help by internalizing the consequences of unemployment and fiscal externalities. The authorities recognized that achieving a consensus would be difficult but were determined to fill the current vacuum by implementing new legislation in the fall.

\footnotetext{
${ }^{22}$ The employer's federation has estimated that the pretax cost (the "earnings requirement") to the buyer of private services from a craftsman earning twice the average wage is close to nine times the craftman's aftertax retained earnings. Comparable ratios internationally include approximately $5 \frac{1}{2}$ for the EU and just over three for the United States.
} 


\section{Pensions}

33. The proposal to reform the pension system (see Box 2) was now being completed and was expected to be implemented in 2001. The rationale for the reform was to link benefits more closely to contributions, allow a portion of funds to be privately invested, insure the long-run solvency of the system, and introduce additional flexibility into retirement options. In terms of financial solvency, the authorities expected the National Pension Fund to remain in surplus under the new system provided that real income grows by about 2 percent per annum and the Fund earns a real rate of return of at least 3 percent. The authorities argued that these assumptions were reasonable and conservative, because a potential output growth rate of at least 2 percent per annum was widely accepted and the average annual return on the assets of the Pension Fund over the 1994-98 period had been 10 percent. Moreover, if the future obligations of the pension system proved to be under funded, a trigger mechanism would be implemented to reduce the indexation formula applied to annuities. Details of that mechanism, however, had still to be determined.

34. The staff welcomed the new system and encouraged the authorities to clarify the specific trigger mechanism as soon as possible. The staff underscored that the inclusion of a trigger mechanism was essential to ensure that the system was robust to possible future upward revisions to demographic projections and downward revisions to the projected rate of income growth or return on investments. ${ }^{23}$ The staff also underscored the importance of containing pension-related expenditures because other age-related expenditures such as disability and survivor payments and health charges would generate additional financial strains on the budget in the future. ${ }^{24}$

${ }^{23}$ Historically, sizeable upward revisions have been made to demographic projections. From 1994 to 1997, demographic projections of life expectancy in 2050 had increased by $31 \frac{1}{2}$ years for men and $2 \frac{1}{2}$ years for women. Moreover, although the potential GDP growth rate is currently around 2 percent, the staff forecasts a decline in the rate over the longer run, as the working-age population is expected to stop growing after 2005 .

${ }^{24}$ According to staff projections, disability and health-related payments will increase from 10 percent of GDP in 1998 to more than 13 percent in 2050 . Assuming that disability pensions continue to be indexed to the CPI and not the wage bill, the ratio of disability expenditures to GDP will fall over time as the working-age population stays fairly constant. Other health-related expenditures, however, will increase fairly rapidly. (Once disability pensioners turn 65, they are automatically transferred to the old-age pension system and are not included in these calculations.) See Chapter III in "Sweden-Selected Issues" (August 1999). 


\section{Privatization}

35. The current emphasis of the Government is on improving the performance of publicly owned enterprises, rather than selling them. One of the most recent innovations was the creation of an enterprise unit within the Ministry of Industry that had been given a mandate to enhance the value and effectiveness of the public companies under its portfolio. ${ }^{25}$ The unit's goal is to improve the management of these companies by nominating a professional and transparent Board with clear objectives. One of the first assignments of the unit was to prepare Telia/Telenor for partial privatization over the next 12 months. ${ }^{26}$ That expected sale and the liquidation of the Government's holdings in the pharmaceutical company Pharmacia and Upjohn earlier this year are reflected in sizeable privatization revenues for 1999-2000 (Table 4) and in the rapid amortization of public debt discussed above (I 12). The staff welcomed the new emphasis on shareholder value, stressed the importance of persisting with the privatization strategy, and encouraged the authorities to foster competition in the sectors in which public enterprises retained large market power.

\section{The financial sector}

36. Since the Swedish banking crisis of the early 1990s, the general awareness, management, and supervision of financial system risks has been strengthened quite significantly. ${ }^{27}$ The supervision authorities indicated their awareness of risks from international financial turbulence and explained their monitoring procedures. ${ }^{28}$ The authorities pointed to generally improved risk management in banks and risk evaluation by

${ }^{25}$ The portfolio, valued at Skr 500 billion (equivalent to nearly 20 percent of the market value of companies listed on the Stockholm stock exchange), includes Telia (telecommunications), Vattenfall (power generation and distribution), government holdings in MeritaNordbanken (banking), the Post Office, SJ (railway), and SAS Sweden (airline).

${ }^{26}$ In January, Telia and Telenor (Telia's Norwegian counterpart) agreed to merge and announced that one third of the new company would be privatized.

${ }^{27}$ The Riksbank began comprehensive monitoring of the financial system in 1997 and initiated a series of semi-annual reports on financial markets. The Riksbank's monitoring and reporting complements the work of the Financial Supervision Authority, which is the supervisor for banks and other financial institutions. For a more detailed report on recent and ongoing developments in the financial sector and its oversight, see Chapter IV in "Sweden-Selected Issues" (August 1999).

${ }^{28}$ The most recent Riksbank reports (November 1998 and May 1999) concluded that the post-Asia rise in risks in the bank sector did not give cause for major concerns at this stage, but counterparty and settlement risk exposures-mainly to industrial-country banks - had built up substantially in the last few years and would require close watching. 
equity analysts; the upgrading of the legislative and regulatory framework (including incorporation of EU directives, especially on capital adequacy); the refocusing of supervision toward more qualitative assessments of risk management processes and internal controls; and detailed contingency planning to deal with future crises. The authorities were nonetheless aware that further progress was required. Identified priorities for additional improvements included the modification of capital adequacy rules in concert with the evolution of Basle standards; better monitoring of bank capital positions; clearer regulation and supervision of complex financial groups; further clarification of circumstances calling for home rather than host country supervision of multinational institutions; and improved standards in securities markets.

\section{The authorities reported that the Swedish financial system was well prepared for} the Y2K problem. Considerable work had been done in ensuring that the main functions of the financial structure would be able to cope with this adjustment, and the Riksbank had developed contingency plans for providing manual means of payment. Moreover, the Riksbank was maintaining a large stockpile of additional banknotes that could be supplied in the event of a sharp increase in demand, ${ }^{29}$ while banks have ample liquid assets to be able to finance the purchase of these additional notes from the Riksbank if required.

\section{Other Issues}

38. Although Sweden has long been a strong proponent of free trade, its accession to the European Union in 1995 and its consequent participation in the Common Agricultural Policy (CAP) have somewhat constrained its ability to act in that arena. The authorities confirmed their intention to work toward further reform of the CAP. Regarding the forthcoming WTO negotiations on agriculture, the authorities expressed their wholehearted agreement with the aim of placing development goals and the integration of developing countries into the world economy at the forefront of the agenda. If this round of negotiations is to succeed, all parties must acknowledge the central importance of access to EU and other industrial-country markets for agricultural products from developing countries.

39. As announced in the spring 1999 budget bill, the authorities confirmed that official development assistance (ODA)-after considerable cutbacks since 1992 in response to the fiscal crisis-would be gradually restored beginning in 2000. By 2002, ODA would reach 0.74 percent of GDP, up from 0.70 percent of GDP in 1999. Sweden stands in fourth place among industrial countries (after Denmark, Norway, and the Netherlands) in ODA relative to GDP.

${ }^{29}$ The stockpile amounts to some SKr 100 billion, which allows for more than a doubling of the current amount of issue ( $\mathrm{SKr} 80$ billion). 


\section{STAFF APPRaISAL}

40. Sweden is undertaking a remarkable transformation of its economy, and it already has much to show from it. Four successes stand out. First, the safety and profitability of the banking and financial structure have been restored after the crisis and recession of the early 1990s. Second, starting from a deficit of more than 12 percent of GDP early in this decade, the government accounts are now in surplus, and the prospect is for a continuing surplus and declining debt in the years to come. Third, the Riksbank-armed with an effective inflationtargeting policy - has achieved price stability and has the tools to cope with any resurgence of inflationary pressures. Fourth, these strengthened policies have helped Sweden weather the international turbulence of the past year and have generated substantial economic growth. With a solid financial position and with economic policies that in most respects are not out of line with the rest of Europe, Sweden has reason to feel confident as it approaches a decision on whether to join the European Monetary Union.

41. The most obvious economic challenge for the Government now is to persist with and build on these transformed policies. The second and even more important challenge is to broaden and intensify the structural changes that will enable Sweden to respond more fully and flexibly to developments in Europe and in the global economy. Even after the recently completed program of fiscal consolidation and the ongoing program to restructure stateowned enterprises, the economic role of the government (taxing, spending, and regulating) remains large in comparison with other industrial countries, and rigidities in the labor market remain an impediment to growth. These two challenges are related: For Sweden to consistently achieve a higher growth rate requires not more demand stimulus but more reform.

42. The clearest distortions in the Swedish economy arise from the tax structure and the wage-bargaining process. Marginal tax rates are high and compounded, and wage differentiation is compressed and cannot respond flexibly to shifts in market conditions. As a result, labor-intensive activities generally suffer. While an ambitious medium-term employment goal has been established, for 80 percent of the working-age population to be employed by 2004 , special education programs in isolation are unlikely to achieve the goal. A flexible and well balanced labor market will require a comprehensive reform of labor taxation and unemployment insurance, and steps leading to a greater and more rational degree of wage differentiation.

43. The central goal for fiscal policy - averaging a fiscal surplus of 2 percent of GDP over the business cycle-is appropriately challenging. If the Government can continue to meet this objective, Sweden will probably exceed the Maastricht criteria for participation in EMU, will put the pension system on a sound financial footing, and will not have to adopt an overly tight monetary policy to control aggregate demand. The goal obviously cannot be reached, however, unless the Government is prepared to allow the surplus to rise above 2 percent when demand is particularly strong, as it may well be in the next few years. The ceilings on government spending that have been set since 1997 are crucial, both for maintaining fiscal discipline and for giving the private sector space in which to flourish. In 
view of the need to reduce the overall economic role of government in order to prepare for the next decade of challenges, adhering to the ceilings that have been announced for 1999 through 2002 and not raising them in real terms in later years are minimum requirements for fiscal policy. Earlier and more detailed contingency plans for specific spending cuts to counter overruns in entitlement spending, presented as part of a longer-term reform program, would improve the credibility of the ceilings.

44. If growth continues as expected and the spending ceilings are not breached, some reduction in taxation will be possible over the next few years, providing the opportunity to begin to tackle the distortions mentioned above. Care will have to be taken, however, to keep tax cuts from stimulating demand while the economy is very close to capacity. Priority should be given to reducing those taxes that are causing the greatest distortions, including those on wealth as well as labor and capital income. Cuts in government spending below the current ceilings should be introduced as an adjunct to any major tax-cut package.

45. The recent agreement to link pension benefits more closely to contributions and to allow a portion of pension funds to be privately invested is welcome, both because these changes will help rationalize the pension system and because they should reduce the danger of fiscal pressures arising from funding deficiencies. These benefits will be greatly enhanced if agreement is reached soon on a trigger mechanism to adjust indexation of pensions if the initial assumptions turn out to be overstated. Consideration should also be given to raising the portion of funds that can be invested in privately managed accounts.

46. Monetary policy also has a strong foundation and is appropriately balanced. Targeting a low inflation rate has been the centerpiece of Riksbank policy since 1993 and must be judged a success. As long as the Riksbank and the European Central Bank are pursuing similar inflation targets and no large unexpected shocks or cyclical asymmetries occur, this strategy is likely to continue to produce a reasonably stable exchange rate and price level. A decision to join EMU would introduce new technical challenges but would not be expected to force a change in the broad policy strategy.

47. While inflation in the headline CPI has been persistently below 1 percent for the past three years, this has mainly been the result of changes in interest rates and indirect taxes. As the Riksbank itself has stressed and has recently clarified, a balanced and stable strategy for adjusting interest rates must be based on longer term inflation considerations. To further improve the clarity and credibility of interest rate policy, the Riksbank would do better to place greater emphasis on the underlying rate of inflation by adopting a target that excludes at least the effects of changes in interest rates.

48. The authorities have greatly strengthened their regulation and supervision of the financial system in recent years, and both they and market participants have significantly improved their awareness and management of systemic risks. Nonetheless, appropriate risk management and supervision are moving targets in the best of times, and a high degree of vigilance remains necessary. One present danger is that banks may rely unduly on meeting the regulatory minima for capital backing and other prudential standards rather than forming 
their own independent assessments of appropriate capital backing for different exposures. The authorities are urged to continue to strengthen the supervisory infrastructure while monitoring the evolution of financial system risks and vulnerabilities.

49. Sweden's macroeconomic data are comprehensive, published in a regular and timely fashion, and adequate for surveillance (Appendix III). Nonetheless, the quality and timeliness of wage statistics could be improved, and the development of quarterly budgetary data on a national accounts basis and of estimates for the structural budgetary position would be helpful. The adoption of ENA95 as the standard for estimating national accounts is welcome and will assist with international comparisons; those data will become more useful if the historical data (currently provided only from 1993) can be extended.

50. It is proposed that the next Article IV consultation with Sweden be held on the standard twelve month cycle. 


\section{Sweden: Basic Data}

Area

Population (March 1998)

Labor force (1997 average)

GDP per capita (1997)

Exchange rate (February 1999)

Social and Demographic Indicators (1990)

Life expectancy at birth

Male: 74

Female: 80

Infant mortality (aged under 1) in percent of live births:

Population per physician:

Population per hospital bed (1989):

\section{Economic Data}

\section{Demand and Supply (at constant prices)}

GDP

Total domestic demand

Private consumption

Public consumption

Gross fixed investment

Business

Public

Housing

Imports of goods and nonfactor services

Exports of goods and nonfactor services
449,964 square kilometers

8.85 million

4.26 million

SDR 19,518

SKr 7.95 per US\$1

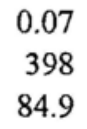

84.9

Selected domestic indicators

Unemployment rate (in percent of

. labor force)

$\begin{array}{llllll}1993 & 1994 & 1995 & 1996 & 1997 & 1998\end{array}$

Hourly labour costs (industry)

Productivity (industry) $1 /$

GDP deflator

Consumer prices (average)

Broad money (M3)

Three-month interbank rate

Ten-year government bond yield

$\begin{array}{rrrrrr}8.2 & 8.0 & 7.7 & 8.0 & 8.0 & 6.5 \\ 0.1 & 3.3 & 6.2 & 6.7 & 4.4 & 3.3 \\ 6.6 & 9.2 & 5.8 & 2.5 & 6.5 & 2.2 \\ 2.6 & 2.4 & 3.7 & 1.0 & 1.2 & 0.8 \\ 4.6 & 2.2 & 2.5 & 0.5 & 0.5 & -0.1 \\ 4.0 & 0.3 & 2.7 & 11.4 & 1.3 & 2.1 \\ 8.5 & 7.6 & 8.8 & 6.0 & 4.4 & 4.4 \\ 8.5 & 9.4 & 10.2 & 8.0 & 6.7 & 5.0\end{array}$

Sources: Data provided by the Swedish autorities; and staff calculations.

1/ National income data. 
Sweden: Basic Data (Continued)

(In percent of GDP unless otherwise noted)

\begin{tabular}{|c|c|c|c|c|c|c|}
\hline & 1993 & 1994 & 1995 & 1996 & 1997 & 1998 \\
\hline Gross saving & 11.3 & 14.5 & 17.6 & 17.0 & 17.6 & 18.9 \\
\hline Public sector & -7.6 & -7.2 & -5.0 & -0.1 & 1.2 & 2.8 \\
\hline Private sector & 18.9 & 21.7 & 22.6 & 17.0 & 16.3 & 16.1 \\
\hline Gross investment & 14.2 & 13.7 & 14.6 & 14.8 & 13.7 & 14.4 \\
\hline Public sector & 2.4 & 2.5 & 2.2 & 2.0 & 1.8 & 1.8 \\
\hline Private sector & 11.8 & 11.2 & 12.4 & 12.8 & 11.9 & 12.7 \\
\hline $\begin{array}{l}\text { Household saving rate } \\
\text { (in percent of dispose income) }\end{array}$ & 8.3 & 80 & 63 & 44 & 11 & 12 \\
\hline \multicolumn{7}{|l|}{ General Government } \\
\hline Financial balance & -12.3 & -10.3 & -7.8 & -2.1 & -0.7 & 2.2 \\
\hline Local authorities & 0.7 & -0.2 & -0.1 & 0.2 & -0.4 & -0.1 \\
\hline & \multicolumn{6}{|c|}{ (Annual percentage change) } \\
\hline \multicolumn{7}{|l|}{ Selected External Indicators } \\
\hline \multicolumn{7}{|l|}{ Real effective exchange rate } \\
\hline (relative normalized ULC) & -23.9 & -2.9 & -1.7 & 10.4 & -5.3 & -3.0 \\
\hline Export volume (merchandise) & 8.7 & 15.6 & 8.1 & 5.5 & 10.9 & 6.7 \\
\hline Import volume (merchandise) & 1.4 & 14.1 & 8.4 & 1.0 & 8.9 & 8.9 \\
\hline Terms of trade (f.o.b./c.i.f.) & -3.3 & 0.4 & 4.6 & -1.4 & -1.0 & 0.5 \\
\hline & \multicolumn{6}{|c|}{ (In billions of Swedish kronor) } \\
\hline \multicolumn{7}{|l|}{ Balance of Payments } \\
\hline Trade balance & 53.3 & 67.1 & 109.1 & 119.1 & 133.1 & 130.9 \\
\hline Exports, f.o.b. & 385.9 & 464.6 & 573.5 & 572.0 & 636.4 & 675.9 \\
\hline Imports, c.i.f. & 332.6 & 397.6 & 464.5 & 453.0 & 503.4 & 544.9 \\
\hline Invisible balance & -82.8 & -61.3 & -69.8 & -75.5 & -82.4 & -92.9 \\
\hline Current balance & -29.5 & 5.8 & 39.3 & 43.6 & 50.7 & 38.0 \\
\hline (in percent of GDP) & -2.0 & 0.4 & 2.4 & 2.6 & 2.9 & 2.1 \\
\hline Financial account & $\ldots$ & $\cdots$ & $\ldots$ & $\ldots$ & -34.9 & 32.5 \\
\hline \multicolumn{7}{|l|}{ Official reserves 4/ } \\
\hline SDR billion & 14.1 & 16.1 & 16.3 & 13.5 & 8.2 & 10.2 \\
\hline In weeks of imports & 25.0 & 22.9 & 18.3 & 15.4 & 9.0 & 11.2 \\
\hline Net foreign assets 1 / (in percent of GDP) & & $\cdots$ & $\cdots$ & $\ldots$ & -44.2 & -39.4 \\
\hline
\end{tabular}

1/ Excluding capital transfers

2/ Change in ratio of real effective exchange rate based on manufacturing export unit values to real effective exchange rate based on unit labor costs.

3/ New definitions were adopted in October 1997 and consistent data are available only for 1997 and 1998.

4/ The decline in external reserves in 1997-98, notwithstanding current account surpluses, reflect the winding down of the Riksbank's forward contracts which had been used to boost reserves in previous years. 
Sweden: Fund Relations

As of June 30, 1999

I. Membership Status: Joined: 08/31/1951; Article VIII

II. General Resources Account: Quota

Fund holdings of currency

Reserve position in Fund

Operational budget transfers (net)

III. SDR Department:

Net cumulative allocation

Holdings
SDR Million

$2,395.50$

$1,475.44$

920.07

$-2.00$

SDR Million

246.53

299.69
\%Quota

100.0

61.6

38.4

\%Allocation

100.0

121.6

IV. Outstanding Purchases and Loans: None

V. Financial Arrangements: None

VI. Projected Obligations to Fund: None

VII. Exchange Rate Arrangements: The Krona has been floating since November 19, 1992.

Under Decision 144-(52/51), Sweden has notified the Fund that it has lifted exchange restrictions vis-à-vis: the Socialist People's Libyan Arab Jamahiriya and areas of the Republic of Bosnia and Herzegovina under the control of the Bosnian Serb forces. Sweden has amended restrictions vis-à-vis the Federal Republic of Yugoslavia (Serbia and Montenegro) and maintains restrictions vis-à-vis Angola (EBD/96/91, 7/12/96) and Iraq (EBD/90/286, 9/10/90).

VIII. Article IV Consultation: Discussions for the 1998 Article IV consultation were held in Stockholm, June 3-10, 1998, and concluded by the Executive Board on September 14, 1998.

IX. The Article IV consultations with Sweden are on the standard twelve-month cycle. 


\section{Sweden: Core Statistical Indicators}

as of June 30, 1999

\begin{tabular}{|c|c|c|c|c|c|c|c|c|c|c|c|c|}
\hline & $\begin{array}{l}\text { Exchange } \\
\text { Rates }\end{array}$ & $\begin{array}{c}\text { International } \\
\text { Reserves }\end{array}$ & $\begin{array}{l}\text { Central } \\
\text { Bank } \\
\text { Balance } \\
\text { Sheet }\end{array}$ & $\begin{array}{c}\text { Reserve/ } \\
\text { Base } \\
\text { money }\end{array}$ & $\begin{array}{l}\text { Broad } \\
\text { Money }\end{array}$ & $\begin{array}{l}\text { Interest } \\
\text { Rates }\end{array}$ & $\begin{array}{l}\text { Consumer } \\
\text { Price } \\
\text { Index }\end{array}$ & $\begin{array}{l}\text { Exports/ } \\
\text { Imports }\end{array}$ & $\begin{array}{l}\text { Current } \\
\text { Account } \\
\text { Balance }\end{array}$ & $\begin{array}{c}\text { Overall } \\
\text { Government } \\
\text { Balance }\end{array}$ & GDP/GNP & External Debt \\
\hline $\begin{array}{l}\text { Date of Latest } \\
\text { Observation }\end{array}$ & $\begin{array}{c}\text { June 30, } \\
1999\end{array}$ & $\begin{array}{c}\text { June } 15, \\
1999 \\
\end{array}$ & $\begin{array}{c}\text { June 15, } \\
1999\end{array}$ & $\begin{array}{l}\text { May } \\
1999\end{array}$ & $\begin{array}{l}\text { May } \\
1999\end{array}$ & $\begin{array}{c}\text { June } 30, \\
1999\end{array}$ & $\begin{array}{l}\text { May } \\
1999\end{array}$ & $\begin{array}{l}\text { May } \\
1999\end{array}$ & $\begin{array}{l}\text { April } \\
1999 \\
\end{array}$ & End-1998 & $\begin{array}{c}\text { 1st Quarter } \\
1999\end{array}$ & End-1998 \\
\hline Date Received & $\begin{array}{c}\text { June } 30, \\
1999 \\
\end{array}$ & $\begin{array}{c}\text { June 23, } \\
1999 \\
\end{array}$ & $\begin{array}{c}\text { June } 23 \text {, } \\
1999 \\
\end{array}$ & $\begin{array}{c}\text { June 24, } \\
1.999 \\
\end{array}$ & $\begin{array}{c}\text { June 24, } \\
1999 \\
\end{array}$ & $\begin{array}{c}\text { June 30, } \\
1999\end{array}$ & $\begin{array}{c}\text { June } 15, \\
1999\end{array}$ & $\begin{array}{c}\text { June } 24, \\
1999 \\
\end{array}$ & $\begin{array}{c}\text { June 15, } \\
1999 \\
\end{array}$ & $\begin{array}{c}\text { April 14, } \\
1999\end{array}$ & $\begin{array}{c}\text { June 15, } \\
1999 \\
\end{array}$ & June 15,1999 \\
\hline Frequency of Data & Daily & Weekly & Weekly & Monthly & Monthly & Daily & Monthly & Monthly & Monthly & Annually & Quarterly & Annually \\
\hline $\begin{array}{l}\text { Frequency of } \\
\text { Reporting }\end{array}$ & Daily & Weekly & Weekly & Monthly & Monthly & Daily & Monthly & Monthly & Monthly & Bi-annual & Quarterly & Annually \\
\hline Source of Update & Commercial & Riksbank & Riksbank & Riksbank & Riksbank & Commercial & Commercial & $\begin{array}{l}\text { Statistics } \\
\text { Sweden } \\
\end{array}$ & Riksbank & \begin{tabular}{|c|c}
$\begin{array}{c}\text { Ministry of } \\
\text { Finance }\end{array}$ \\
\end{tabular} & $\begin{array}{c}\text { Statistics } \\
\text { Sweden }\end{array}$ & Riksbank \\
\hline Mode of Reporting & On Line & Publication & Publication & On-line & On-line & On Line & On Line & On-line & On-line & Publication & On-line & On-line \\
\hline Confidentiality & Public & Public & Public & Public & Public & Public & Public & Public & Public & Public & Public & Public \\
\hline $\begin{array}{l}\text { Frequency of } \\
\text { Publication }\end{array}$ & Daily & Weekly & Weekly & Weekly & Monthly & Daily & Monthly & Monthly & Monthly & Bi-annual & Quarterly & Annually \\
\hline
\end{tabular}




\section{IMF Concludes Article IV Consultation with Sweden}

On August 25, 1999, the Executive Board concluded the Article IV consultation with Sweden. ${ }^{1}$

\section{Background}

The Swedish economy came under severe pressure in the early 1990s when a number of forceshigh wage and price inflation, the bursting of a bubble in real estate prices and bank shares, a consequent banking crisis, and a forced exit from the currency peg against the Ecu-brought on the country's deepest recession since the 1930s. The damaging effects from the combination of high public sector employment, generous welfare benefits, high tax rates, and a high sensitivity of government finances to the business cycle were laid bare by the recession and led to a loss of confidence in the credibility of Sweden's financial policies. Since then the authorities have done much to restore stability and credibility, through a swift resolution of the banking crisis and the adoption of solid macroeconomic policies centered on inflation targeting and a strong fiscal consolidation program. The success of these policies has been evidenced since 1993 by exceptionally low inflation and a competitive and generally stable floating exchange rate; and more recently by a fiscal surplus and strong economic growth.

Progress on structural reform -especially on taxation and wage formation-has been less pronounced. Real GDP growth accelerated to 2.9 percent in 1998, as a result of a strengthening of domestic demand. Private consumption was aided by sizeable real wage increases, declining unemployment, increased government transfers to households, and rising asset prices, while investment was boosted by a combination of improved profit conditions, a healthy economic outlook, and lower interest rates. Employment rose by $1 \frac{1}{2}$ percent in 1998, and by a further 2 percentage points during the first half of 1999 , while the open unemployment rate fell to $51 / 2$ percent. Including the $3 \frac{1}{2}$ percent of the work force that is still enrolled in labor market programs, total unemployment

\footnotetext{
${ }^{1}$ Under Article IV of the IMF's Articles of Agreement, the IMF holds bilateral discussions with members, usually every year. A staff team visits the country, collects economic and financial information, and discusses with officials the country's economic developments and policies. On return to headquarters, the staff prepares a report, which forms the basis for discussion by the Executive Board. At the conclusion of the discussion, the Managing Director, as Chairman of the Board, summarizes the views of Executive Directors, and this summary is transmitted to the country's authorities. In this PIN, the main features of the Board's discussion are described.
} 
is around 9 percent. The external current account position has been in surplus since Sweden abandoned its fixed exchange rate in 1992.

Fiscal adjustment has been dramatic since the implementation of the consolidation program in 1994. A combination of spending cuts and tax increases, augmented by reduced interest costs, produced a structural improvement amounting to 10 percent of GDP and led to a fiscal surplus of 2.2 percent in 1998. Even so, total government expenditure and taxation account for well over half of GDP and are far above the industrial-country average. Looking ahead, expenditure control is being reinforced by a comprehensive reform of the old-age pension system and supplemented by a nascent program of restructuring and privatizing public-sector enterprises. These policies are expected to reduce consolidated gross debt from 75 percent of GDP in 1998 to 51 percent in 2002, while net debt would fall from 15 percent to zero.

Consumer prices have been stable over the past 12 months, while the underlying inflation rate (which excludes the effects of changes in interest rates, indirect taxes, and subsidies) has been 1.2 percent. With inflation remaining that subdued, the Riksbank was able to lower short-term interest rates gradually by a total of almost $1 \frac{1}{2}$ percentage points. With no further change in interest rates, the Riksbank projects that the gradual elimination of unutilized resources in the economy will push underlying inflation to about 2 percent (the central point of the target range of 1-3 percent) over the next two years.

With fiscal policy turning slightly expansionary and interest rates staying low, conditions are in place for a continuing recovery. Growth is projected to remain around $23 / 4$ percent through 2001 , with favorable employment growth pushing the employment-population ratio toward the official objective of 80 percent. The open unemployment rate is projected to decline to 5 percent in 2001 .

\section{Executive Board Assessment}

Executive Directors welcomed Sweden's successful efforts in recent years to restore macroeconomic balance by implementing prudent fiscal and monetary policies. The shifts from a large fiscal deficit in the early 1990s to a surplus in 1998 and from high inflation to stable prices were major achievements. Directors noted that the program of fiscal consolidation pursued since 1994 was primarily responsible for the strengthening of the public finances, and that the inflation targeting approach to monetary policy had been successful in achieving low inflation. Directors also reiterated their praise for the way Sweden had restored the soundness and profitability of the banking and financial sectors after the crisis of the early 1990s. In the past year, these strengthened policies and institutions had helped Sweden to weather the international turbulence in financial markets and to generate substantial economic growth. Directors considered, however, that the main challenge now facing the authorities is to build on their successful macroeconomic policies, and to implement more far-reaching structural reforms-especially on taxation and wage formation-so as to sustain strong economic growth and reduce unemployment.

Directors agreed that conditions seemed favorable for a continuation of growth in the near term. Interest rates were low, the fiscal consolidation program was largely complete, and a general economic recovery was under way in Europe. Although it was difficult to make an accurate judgment of the amount of slack in the economy, they agreed that some room for expansion remained, and that the strong pattern of growth expected in Sweden did not pose an immediate threat to stability. 
Directors expressed concern, however, about the continuing large increases in real wages, and noted that bottlenecks and inflationary pressures could reemerge as the economy approached capacity limits in one or two years. In these circumstances, they stressed the need for the authorities to remain vigilant and to be ready to act preemptively to stifle any inflationary pressures. Directors also cautioned that additional demand stimulus was unnecessary at this time, and saw scope for structural reform to enhance the economy's flexibility further.

Directors viewed the central goal for fiscal policy-to average a fiscal surplus of 2 percent of GDP over the business cycle-as appropriate. While noting Sweden's commitment to social welfare, Directors observed that the economic role of government was still remarkably pervasive, and they considered that further reductions in taxation-which would require lower spending levels-would enhance economic efficiency and the prospects for economic growth. Directors welcomed the specification of ceilings on central government spending, and noted that adherence to the announced ceilings through 2002 would be crucial for achieving the fiscal goals. A few Directors also noted the importance of spending control by local authorities.

Directors supported the authorities' stance on monetary policy. Adherence to an inflation target had enhanced both transparency and credibility, and the central bank had been able to reduce interest rates cautiously as inflationary pressures had gradually subsided in recent years. Although inflation in the consumer price index had been persistently below the lower end of the target range for the past three years, Directors recognized that the gap had resulted primarily from changes in interest rates and indirect taxes. To enhance the clarity and credibility of monetary policy further, some Directors encouraged the Riksbank to switch to an inflation target that excluded at least the effects of changes in interest rates, such as the European Union's Harmonized Index of Consumer Prices or an index of underlying inflation.

Directors welcomed Sweden's decision to keep open the possibility of joining the European Monetary Union (EMU) within a few years. Although some Directors wondered if Sweden would have much to gain from joining the EMU-since it already enjoyed both stable prices and a stable exchange rate-several of them thought that Sweden would benefit from the greater unification with other European economies that would come with EMU participation. Other Directors noted that, given Sweden's recent economic progress, the decision was at least as much political as economic.

Directors noted that the present favorable economic situation provided a good opportunity for Sweden to undertake structural reforms that would be needed, sooner or later. In this connection, they observed that the main distortions in the Swedish economy arose from the tax structure and the wage bargaining process. Marginal tax rates were high, and wage differentiation was compressed. Directors welcomed the authorities' intention to reduce taxes over the next few years, while stressing that care should be taken to keep tax cuts from stimulating demand while the economy was close to capacity. Priority should be given to reducing those taxes that are causing the greatest distortions, including those on wealth as well as labor and capital income.

Directors stressed that tax reforms should be accompanied by a comprehensive reform of the unemployment insurance system and greater wage differentiation in order to foster employment creation in the private sector. They considered that reform of the labor market should not be delayed, as such reform would help the authorities to achieve their ambitious employment objectives. Directors considered that a reduction in the tax wedge, streamlining of unemployment 
benefits, and reform of the wage bargaining process should receive the highest priority, as these would enhance Sweden's overall competitiveness. In this regard, they regretted the slow progress in implementing the recommendations of the Öberg Commission on reforming the wage bargaining process, and thus encouraged the authorities to foster the necessary public consensus in favor of labor market reforms.

Directors welcomed the impending pension reform, which will link benefits more closely to contributions and is expected to ensure the continued solvency of the public pension system. Also on structural reforms, some Directors recommended that the authorities accelerate the process of privatization of state-owned enterprises, while other Directors endorsed the policy of first improving the efficiency and performance of these enterprises.

Directors expressed satisfaction with the strengthening of the regulation and supervision of the financial system in recent years. Nonetheless, they encouraged the authorities to continue this process while monitoring closely the evolution of financial system risks and emerging vulnerabilities.

Directors recorded their appreciation for Sweden's aid program, and welcomed the authorities' decision to begin restoring the level of official development assistance after the cutbacks of recent years.

Public Information Notices (PINs) are issued, (i) at the request of a member country, following the conclusion of the Article IV consultation for countries seeking to make known the views of the IMF to the public. This action is intended to strengthen IMF surveillance over the economic policies of member countries by increasing the transparency of the IMF's assessment of these policies; and (ii) following policy discussions in the Executive Board at the decision of the Board. As part of a pilot project, the staff report (use the free Adobe Acrobat Reader to view this pdf file) for the 1999 Article IV consultation with Sweden is also available on the IMF's website (http://www.imf.org). 
Sweden: Selected Economic Indicators

$\begin{array}{lllllll}1996 & 1997 & 1998 & 1999 & 1 / 2000 & 1 /\end{array}$

Real economy (change in percent)

Real GDP

Domestic demand

CPI

Total unemployment rate (in percent)

Of which: Labor market programs

Gross national saving 2/

Gross national investment 2/

Public finance (in percent of GDP)

General government financial balance

General government debt

Money and credit (end-year, percent change)

MO

M3

Interest rates (year average)

Three-month interbank rate

Ten-year government bond yield

Balance of payments (in percent of GDP)

Trade balance

Current account

Reserves (gold valued at SDR 35 per ounce end of period, in billions of SDRs)

Exchange rates

Exchange rate regime

Present rate (August 27, 1999)

Nominal effective rate $(1995=100)$

Real effective rate $(1995=100) 5 /$

$\begin{array}{rrrrr}0.9 & 2.2 & 2.9 & 2.8 & 3.0 \\ -0.3 & 0.9 & 3.9 & 2.5 & 2.7 \\ 0.5 & 0.5 & -0.1 & 0.2 & 1.0 \\ 12.5 & 12.3 & 10.4 & 9.4 & 9.0 \\ 4.5 & 4.3 & 3.9 & 3.6 & 3.6 \\ 17.0 & 17.6 & 18.9 & 17.4 & 17.8 \\ 14.6 & 14.1 & 15.1 & 15.6 & 16.0\end{array}$

$\begin{array}{rrrrr}-2.1 & -0.7 & 2.2 & 1.8 & 2.1 \\ 77.2 & 76.9 & 75.4 & 67.6 & 62.2\end{array}$

$\begin{array}{rlllll}5.3 & 3.0 & 5.1 & 7.5 & 3 / & \ldots \\ 11.4 & 1.3 & 2.1 & 6.0 & 3 / & \ldots\end{array}$

$\begin{array}{lllll}6.0 & 4.4 & 4.4 & 3.3 & 4 / \\ 8.0 & 6.7 & 5.0 & 5.3 & 4 /\end{array}$

$\begin{array}{lllll}7.1 & 7.7 & 7.3 & 7.0 & 6.7 \\ 2.6 & 2.9 & 2.1 & 1.7 & 1.7\end{array}$

$\begin{array}{lllll}13.45 & 8.19 & 10.18 & 10.31 & 3 /\end{array}$

Floating exchange rate

US $\$ 1=$ SKr 8.34

$\begin{array}{lllll}109.6 & 105.5 & 103.2 & 101.1 & 3 /\end{array}$

$\begin{array}{lllll}110.4 & 104.5 & 101.2 & 97.6 & 3 /\end{array}$

\footnotetext{
1/ Staff projections, except where noted.

$2 /$ In percent of GDP.

3/ June 1999.

4/ July 1999.

$5 /$ Based on relative normalized unit labor costs in manufacturing.
}

Sources: IMF, Intemational Finance Statistics; the Riksbank; and IMF staff projections. 


\section{Statement by Kai Aaen Hansen, Executive Director \\ for Sweden \\ August 25, 1999}

First, my Swedish authorities convey their appreciation to the staff for constructive discussions in Stockholm and for an accurate and balanced report.

The recovery of the Swedish economy is strong. For the first half of 1999 GDP grew by 3.7 percent, considerably stronger than anticipated in earlier forecasts. The strong recovery is expected to continue through the year, pointing to a GDP growth well above 3 percent for 1999. The growth is balanced, with a strong development of domestic demand, in particular private consumption, being reinforced by a stronger than expected increase in exports.

Inflationary pressures continue to be low, which in combination with a high credibility of economic policy, has permitted a continued, supportive stance of monetary policy.

\section{Fiscal Policy}

The fiscal consolidation program has led to a strong structural improvement of the public finances. To secure the gains of fiscal consolidation, the government and the parliament have adopted a medium term goal of a general government surplus of 2 percent of GDP per year over the cycle. Intermediate targets were initially set at 0.5 percent of GDP in 1999, 1.5 percent in 2000 and 2.0 percent in 2001. In the fall of 1998, the intermediate target for year 2000 was raised to 2 percent of GDP and in the Spring Budget Bill of 1999 a goal of 2.0 percent was set also for 2002 .

The system of rolling three-year expenditure ceilings is an important pillar for controlling public expenditure. In the Spring Budget Bill of 1999 the government made the assessment that there was some risk that the expenditure ceilings for 1999 and 2000 would be exceeded. To keep public expenditures under the expenditure ceiling, a number of savings measures, amounting to a total of 7 billion SEK, were introduced. In addition, the government decided on limitation amounts for certain appropriations. The government is prepared to take further steps if necessary to ensure that the expenditure ceiling is maintained.

With unchanged policies, current projections indicate substantial surpluses in the public finances for the coming years, creating room for maneuver for the government. One possibility is to reduce taxes. The government also continues to give priority to secure the quality of health care, education and social services. The magnitude of this room for 
maneuver will continuously be assessed against the development of the cycle to avoid an inappropriately expansive fiscal stance should the economy approach full capacity.

\section{Monetary Policy}

Monetary policy in 1998-99 has been conducted against the background of a gradually shrinking output gap and subdued inflationary expectations. Substantial transitory effects on headline inflation from changes in mortgage interest costs and changes in indirect taxes have contributed to low headline inflation and a rate below the tolerance range of the inflation target. The Riksbank agrees with the staff that, the monetary stance at present is well balanced, although it recognizes that bottlenecks and inflationary pressures could emerge should recent indications of strong growth continue.

One aspect of monetary policy formulation in Sweden discussed in the staff report is how to define an inflation goal in relation to transitory effects. It is a problem familiar to all central banks using an inflation target and it has been analyzed thoroughly within the Riksbank.

In January 1999 the Riksbank gave explicit advice on how the CPI objective should be interpreted. While monetary policy will continue to be conducted with a view to stabilizing CPI inflation at 2 percent over one to two years, the Riksbank will normally disregard transitory factors stemming from e.g. changes in mortgage interest costs and indirect taxes. To facilitate an evaluation of monetary policy the Riksbank will make clear, when policy decisions are taken, which transitory effects it forecasts and disregards. An example is the Riksbank's inflation report in June, where it was stated that in practice monetary policy at nresent is based on an assessment of underlying inflation as measured by UND1X. The difference between CPI and UND1X is that the latter excludes transitory effects from changes in indirect taxes, subsidies and interest rates. The inflation report also contained a forecast for inflation as measured by this definition.

The Riksbank is also considering a reformulation of the inflation target, in line with the recommendation by the staff. However it is important to recognize that all known inflation measures have defects. Therefore, the Riksbank await ongoing work by a CPI inquiry appointed by the government to obtain assistance in the specification of an adequate indicator of underlying inflation as well as the process of finalizing the composition of the EU's Harmonized Index of Consumer Prices. Even after a possible revision of the target variable, the clarification presented in January will be useful. 


\section{Structural Policies}

The labor market situation continues to improve. Open unemployment is now around 5.5 percent, down one percentage point compared to a year ago. Employment growth is very strong, currently increasing at a rate above 2 percent annually.

It is important to ensure that the current labor market improvement can continue without giving rise to inflationary pressures. Thus, emphasis is put on measures that help prevent bottlenecks in the labor market and to curb inflationary pressures in the current upswing. Education and training measures are expected to significantly promote employability, the number of people in active labor market programs is being reduced, while at the same time there is increased emphasis on the needs of the labor market in the design of these programs. The unemployment insurance rules are subject to review, in order to identify changes that will promote job search incentives and labor mobility.

The wage formation is key to a lasting reduction of unemployment. The main responsibility for wage formation lies with the social partners. Later in the fall the government will present a bill with proposals on, inter alia, strengthened mediation procedures.

To sum up, my Swedish authorities agree with the staff that, for the time being, the fiscal and monetary stance is well balanced, although they recognize that bottlenecks and inflationary pressures could emerge should the current strong growth rate continue. Moreover, they agree with the staff report that further measures may be needed in order to foster a sustainable, high growth rate. 